\title{
Exchange Rate Targeting in the Presence of Foreign Debt Obligations
}

\author{
By \\ James Staveley-O'Carroll \\ and
}

Olena M. Staveley-O'Carroll

July 2016

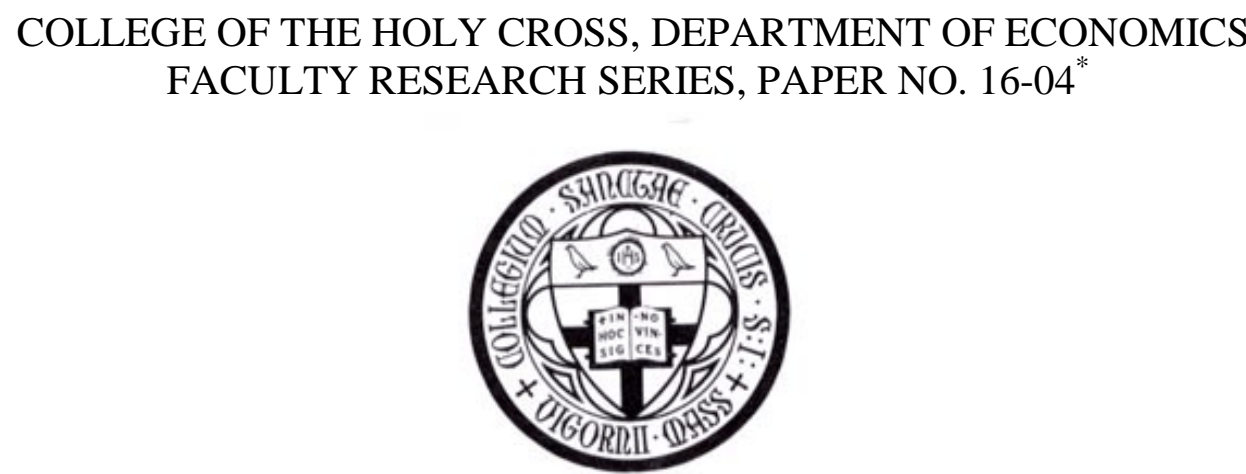

FACULTY RESEARCH SERIES, PAPER NO. 16-04*

Department of Economics

College of the Holy Cross

Box 45A

Worcester, Massachusetts 01610

(508) 793-3362 (phone)

(508) 793-3710 (fax)

http://www.holycross.edu/academics/programs/economics-and-accounting

*All papers in the Holy Cross Working Paper Series should be considered draft versions subject to future revision. Comments and suggestions are welcome. 


\title{
Exchange Rate Targeting in the Presence of Foreign Debt
}

\section{Obligations}

\author{
James Staveley-O'Carroll* \\ Babson College
}

\author{
Olena M. Staveley-O'Carroll ${ }^{\dagger}$ \\ College of the Holy Cross
}

July 15, 2016

\begin{abstract}
We study the impact of foreign debt on the trade-off between the three open economy objectives of a central bank - international risk sharing, the need to facilitate expenditure-switching, and the incentive to tilt international prices to lower the labor effort of domestic households - in a two-country DSGE model with incomplete asset markets and deviations from the purchasing power parity. We find that at low debt levels, a Taylor rule outperforms simple targeting rules. However, the central bank can improve welfare by up to 0.25 percent of consumption via an exchange rate peg when debt-to-GDP ratio reaches 100 percent.
\end{abstract}

Key words: international risk sharing, foreign debt, exchange rate policy.

JEL classification: E52, F32, F41

\section{Introduction}

Cross-border flows of financial capital, which have grown dramatically during the last thirty years, have been accompanied by pronounced asymmetries in the net foreign asset positions of different countries. Many

\footnotetext{
* Economics Division, Westgate Hall, Babson College, 231 Forest Street, Babson Park, MA 02457. Email: jstaveleyocarroll1@babson.edu

$\dagger$ Corresponding author. Department of Economics and Accounting, Box 45A, College of the Holy Cross, One College Street, Worcester, MA 01610. Email: omykhayl@holycross.edu
} 
Asian and Middle Eastern economies have accumulated large quantities of net foreign wealth just as the United States and most countries in Central and Eastern Europe have seen an increase in their international liabilities. While cross-country financial flows bring many benefits, such as international consumption risk sharing and efficient allocation of capital to its most productive uses, they also expose countries to the risk of financial crises (through higher risk premia on foreign borrowing and adverse effects of currency depreciation on the value of existing debt) and may amplify the transmission of foreign shocks to highly indebted economies. In fact, Mykhaylova and Staveley-O'Carroll (2014) demonstrate that high levels of foreign-currency denominated debt coupled with financial market incompleteness significantly lower the degree of international risk sharing (as measured by the consumption-real exchange rate correlation). In a follow-up to this finding, we use a two-country dynamic stochastic general equilibrium (DSGE) model to explore the welfare implications of exchange rate targeting in the presence of significant foreign indebtedness.

The literature on the advisability of exchange rate targeting is vast, and its thorough overview is well beyond the scope of this paper. However, taking the seminal Friedman (1953) paper as the point of departure, we can trace several shifts in the prescription for the optimal monetary policy conduct. Friedman's (1953) traditional recommendation, later repeated in Devereux and Engel (2003) and Gali and Monacelli (2005), was to allow nominal exchange rates to move freely. Country-specific technology shocks require relative price adjustment to shift international demand to the more plentiful product; when goods prices are sticky, this expenditure-switching channel must operate through flexible exchange rates. In fact, the authors found that the optimal monetary policy was isomorphic to that of a closed-economy setup: the central bank should fully stabilize home producer prices. However, the expenditure-switching mechanism needs full and immediate exchange-rate pass-through to prices and a high degree of import-export elasticity to operate properly. Devereux and Engel $(2003,2007)$ observe that if (a) goods prices are sticky in local (country of destination) rather that producer (country of origin) currency, so that exchange-rate pass-through is very low, or (b) imports and exports are complements in consumption so that expenditure-switching efforts produce negligible results, then central banks should contemplate some degree of exchange rate stability to promote international risk sharing. The two objectives - optimal exchange rate adjustment and equalization of international consumptions - are frequently in conflict, and the optimal degree of exchange rate stability 
depends on specific parameters of the model. The root of this dilemma lies in the dual role of the exchange rate as a relative price in both the goods and the asset markets.

Central banks are also able to exploit the monopoly power of their domestic producers to improve consumer welfare, as documented in, for example, Obstfeld and Rogoff (1998) and Corsetti and Pesenti (2001). As long as home and foreign goods are highly substitutable and international financial markets are complete, monetary policy can shift production abroad by improving the terms of trade, thus lowering the labor disutility of home households while leaving their consumption level unaffected. This so-called termsof-trade externality, therefore, calls for some measure of exchange manipulation, as noted in Benigno and Benigno (2003), Corsetti and Pesenti (2005), and De Paoli (2009, 2009b).

If consumers cannot perfectly risk share internationally, however, exploiting the terms of trade externality can be welfare-reducing (De Paoli, 2009b; Rabitsch, 2012). In this setting, policies that promote crosscountry consumption equalization gain more importance. Benigno (2009) reports that in the presence of asymmetries in the net asset positions of different countries, monetary policy can improve risk sharing via the debt valuation effects: if the country receiving a positive productivity shock is an international net debtor, an increase in its consumption can be tempered by a rise in its international liabilities (via depreciation, if the debt is foreign-currency denominated), thus improving the degree of risk sharing.

This last contribution notwithstanding, the impact of foreign debt on the conduct of central banks remains relatively unexplored. Our paper continues the study of the question raised by Benigno (2009) to consider its effect on the degree of international risk-sharing and on the optimal stance of monetary policy. ${ }^{1}$ In contrast to the model in Benigno (2009), in which purchasing power parity holds at all times and the debtor country borrows in its own currency, we model the real exchange rate (RER) dynamics explicitly, so that valuation effects can directly affect the level of foreign debt. In addition to calculating the optimal weight on the real exchange rate in the central bank response function, which we model as a Taylor-type rule, we also rank - based on consumer welfare - the most commonly studied monetary policies in an open economy setting: producer price inflation targeting (the traditional prescription for a closed economy and for some fairly restrictive versions of open economy models; dubbed PPI hereafter), consumer price inflation targeting

\footnotetext{
${ }^{1}$ In a setup closely related to ours, Demirel (2009) investigates the impact of foreign liabilities on the cross-border transmission of monetary policy shocks, but does not pursue the question of optimal policy conduct.
} 
(CPI), and a nominal exchange rate peg (PEG).

Our two-country economy is characterized by sticky prices, incomplete financial markets, and imperfect substitutability of goods within and across national borders. These assumptions give rise to all of the three aforementioned open-economy inefficiencies: expenditure-switching primarily via exchange rate movements (which we will hereafter refer to as ES), imperfect consumption risk sharing (RS), and the terms-of-trade externality (TE). The externalities, in turn, generate two tensions when selecting monetary policy: the need to appreciate (to take advantage of TE) versus depreciate (to offset the internal monopoly power), and the optimality of exchange rate flexibility (for ES) versus stability (to improve RS).

One of the key features of the model is the asymmetry in the net international asset positions of the two countries. Households can trade internationally in only one risk-free nominal bond. One of the two countries is subject to a risk premium on its external liabilities, denominated in foreign currency. The premium is an increasing function of the ratio of net foreign debt to GDP (which we refer to as the net foreign debt ratio, or NFDR), to reflect the observation that a country's borrowing costs are tied to its ability to finance its debt, a measure that can be captured by the NFDR. Fluctuations in output due to productivity shocks alter the ratio of foreign debt to GDP and consequently affect the risk premium on foreign borrowing; additionally, the level of outstanding debt is directly linked to exchange rate movements induced by the shocks. The resulting valuation effects, as well as changes in the interest payments, can reverse the standard international shock transmission mechanisms and reduce cross-border consumption correlation. Thus, the presence of foreign debt has the potential to alter the optimal conduct of monetary policy by changing the relative importance of its risk-sharing objective.

In this setup, a single central bank cannot simultaneously resolve the above two tensions; therefore, our exploration of the trade-off between price and exchange rate stabilization is quantitative in nature. We follow the strategy of many recent papers that use numerical methods to categorize optimal monetary policy using consumer welfare as the criterion. ${ }^{2}$ Since the welfare loss function in an open economy setting has been derived analytically in the papers referenced in the preceding paragraphs, this approach allows us to evaluate the relative strengths of several well-understood mechanisms that link monetary policy stance to

\footnotetext{
${ }^{2}$ See, for example, the works of Kollmann (2004), Cova and Søndergaard (2004), and Wang (2010).
} 
macroeconomic outcomes in a more complex and arguably more realistic setting.

Our main results can be summarized as follows. In the absence of foreign debt, the degrees of risk sharing and of expenditure-switching are high and fairly insensitive to the choice of monetary policy regime. Moreover, there is no tension between the two objectives: following a positive productivity shock in either country, its producer prices need to fall for both ES (to shift demand to the local good) and RS (to transfer some of the local wealth abroad). Because of this insensitivity, the central bank can maximize consumer welfare by exploiting the terms-of-trade externality. In the baseline calibration, the policy that delivers the most appreciated exchange rate is the Taylor rule with a very low weight on CPI inflation and no weight on the real exchange rate. Even though it requires sacrificing a small degree of risk sharing compared to the other three policy options (PPI, CPI, and PEG), the Taylor rule minimizes the home households' labor effort without giving up too much consumption.

The presence of foreign-currency denominated debt changes the relative gains from pursuing the three open economy objectives by significantly reducing the degree of risk sharing through amplification of the wealth transfer. More specifically, when $N F D R=1$, a currency depreciation following an improvement in home productivity impoverishes home households via the debt valuation effect, transfers the majority of the wealth effect abroad, and actually lowers home consumption. To avoid these negative effects, the central bank of a highly indebted economy should aggressively target exchange rate fluctuations by adopting a strict nominal peg.

Our policy prescriptions are essentially robust to changes in several parameters controlling the openeconomy features of the model: the degree of exchange rate pass-through to consumer prices, importexport elasticity, and the level of home bias in consumption. The Taylor rule remains the best policy choice at low debt levels, and the nominal peg delivers the highest consumer welfare with $N F D R=1$, with one exception involving the degree of import-export substitutability. ${ }^{3}$ When imports and exports are complements in consumption, the risk-sharing power of RER fluctuations is reduced: since consumers cannot readily substitute towards goods produced abroad, lower demand for imports prevents foreign households from fully sharing in the home economy windfall, and vice versa. The weakened RS channel reduces the

\footnotetext{
${ }^{3}$ Corsetti, Dedola, and Leduc (2008), Enders and Müller (2009), and Viani (2010), among others, have documented the importance of this parameter for the direction of cross-country shock and wealth transmission.
} 
excessive wealth transfer at high debt levels and makes RER depreciation less detrimental. We find, under this particular parameterization, that CPI targeting outperforms the nominal peg by delivering a slightly more depreciated RER, more risk sharing, and so greater consumer welfare.

These findings relate our paper to another strand of literature, that on the role of valuation effects in the dynamics of external positions. In our model, for example, the policy of producer price stability for $N F D R=1$ results in a two percent real exchange rate depreciation following a shock to home technology, which increases the debt-to-GDP ratio by 20 percent and more than offsets the positive income effect of higher productivity. This echoes the findings in Blanchard et al. (2005), Gourinchas and Rey (2007), and Gourinchas (2008) that exchange rate fluctuations induce significant changes in the net foreign asset position of a country. (These studies remain agnostic as to whether the exchange rate movements behind the valuation effects were central bank-generated or market-driven. $)^{4}$

Finally, our paper contributes to the ongoing discussion of monetary policy conduct in developing economies. A host of empirical evidence indicates that many developing countries, which are typically net debtors in international financial markets, do not allow their exchange rates to float freely; see, among many others, Fischer (2001), Levy-Yeyati and Sturzenegger (2005), and Reinhart (2000). The most commonly used explanation of this phenomenon is "the fear of floating" argument, proposed by Calvo and Reinhart (2002). The authors suggest that large currency depreciation may worsen corporate and financial balance sheets since many liabilities are denominated in a foreign currency. Within our modeling framework, the nominal peg does indeed deliver the highest levels of welfare and risk sharing to economies highly indebted in foreign currencies, as long as imports and exports are substitutes in consumption.

The rest of the paper is organized as follows. Section 2 outlines the theoretical model, and Section 3 describes the mechanisms through which international debt affects international risk sharing. Section 4 lists the values of the model parameters used in simulations, discusses the resulting business cycle properties of the main aggregates, and presents the main results of the paper. Robustness exercises are discussed in Section 5. Finally, Section 6 summarizes the findings and lists several extensions for future research.

\footnotetext{
${ }^{4}$ Ghironi et al. (2015) quantify the relative contributions of valuation and portfolio effects in external adjustment; however, since in their model all prices are flexible, PPP holds, and only equity is traded internationally, changes in a country's net foreign assets are not influenced by exchange rate movements.
} 


\section{The Model}

The model, taken directly from Mykhaylova and Staveley-O'Carroll (2014), belongs to the class of DSGE models that are commonly used for evaluating the effects of different monetary policies in both closed and open economy settings. Below we outline its most salient features and refer the interested reader to the original paper for details.

We consider two countries, home $(H)$ and foreign $(F)$, both of which are populated by infinitely lived households of measure $M$ at home and $M^{*}$ abroad; there is no migration. Monopolistically competitive firms in each country use local labor and capital to produce a continuum of intermediate goods that are then traded internationally. These goods are aggregated into nontradable final goods bundles, which are used for private and public consumption and investment. The model also includes two structural frictions commonly used in the open economy literature: home bias in consumption and incomplete exchange rate pass-through to consumer prices. We follow Devereux and Engel (2007) by assuming that intermediate goods are priced in producer currency, but final goods available for consumption and composed of both imported and locally produced intermediates are priced in local currency. Combined with sticky prices, this setup corresponds to the empirical observation that, in the short-run, exchange rate pass-through into import prices is quite high while consumer price index (CPI) inflation is insulated from exchange rate movements. ${ }^{5}$ The model's stochastic environment is governed by country-specific productivity shocks.

As a matter of notation, subscripts $H$ and $F$ will refer to a good's country of origin; asterisks will indicate that it is consumed in country $F$. For example, $C_{H}^{*}$ denotes consumption of country $H$ 's good in country $F$. The two economies have a similar structure; therefore, most of the equations will be presented only for the home country. Since this framework is quite common in the literature, we relegate the model solution to Appendix A.

\subsection{Firms}

Each country has a continuum of intermediate goods producers indexed by $f$ on the unit interval. At time $t$, each Home producer rents capital $K_{t-1}(f)$ from the domestic households at the rate $R_{t}$, hires a labor

\footnotetext{
${ }^{5}$ See Campa and Goldberg (2005) and Mumtaz, Oomen and Wang (2006) for empirical evidence.
} 
bundle $L_{t}(f)$ at the rate $W_{t}$ and supplies one of the varieties of the domestic intermediate good according to the standard Cobb-Douglas production function

$$
Y_{H, t}^{s}(f)=Z_{t}\left[K_{t-1}(f)\right]^{\nu}\left[L_{t}(f)\right]^{1-\nu}
$$

where $0<\nu<1$, and $Z_{t}$ denotes the level of productivity enjoyed by all the home producers at time $t$. All local varieties are bundled into a composite intermediate good, used by the final goods firms described below, as follows:

$$
Y_{H, t}^{s}=\left[\int_{0}^{1} Y_{H, t}^{s}(f)^{\frac{\sigma_{i n t}-1}{\sigma_{i n t}}} d f\right]^{\frac{\sigma_{i n t}}{\sigma_{i n t}-1}}
$$

where $\sigma_{\text {int }}>1$ is the elasticity of substitution between the different varieties.

Each intermediate producer is free to set its own price level $P_{H, t}(f)$ (foreign firms control $P_{F, t}^{*}(f)$ ), denominated in local currency; by construction, the Law of One Price holds. As in Calvo (1983), home and foreign producers reset their prices each period with a constant probability $\left(1-\alpha_{i n t}\right)$ and $\left(1-\alpha_{i n t}^{*}\right)$, respectively; otherwise, the old prices remain in effect. ${ }^{6}$

A continuum of monopolistically competitive final goods firms combine Home and Foreign intermediate composites into one of the varieties of the Home final good:

$$
Y_{t}^{s}(i)=\left[\mu^{\frac{1}{\eta}}\left[Y_{H, t}^{d}(i)\right]^{\frac{\eta-1}{\eta}}+(1-\mu)^{\frac{1}{\eta}}\left[Y_{F, t}^{d}(i)\right]^{\frac{\eta-1}{\eta}}\right]^{\frac{\eta}{\eta-1}}
$$

where $\eta$ is the elasticity of substitution between home and foreign intermediate goods composites, and $0<\mu<1$ determines the degree of home bias in consumption. These varieties are aggregated into the composite final good $Y_{t}$, used by domestic agents for consumption and investment:

$$
Y_{t}^{s}=\left[\int_{0}^{1} Y_{t}^{s}(i)^{\frac{\sigma_{f}-1}{\sigma_{f}}} d i\right]^{\frac{\sigma_{f}}{\sigma_{f}-1}}
$$

Each period, final goods producers optimally choose their prices $\tilde{P}_{t}$, denominated in the local currency, with probability $\left(1-\alpha_{f}\right)$. The price $P_{t}$ of the composite final good, which represents the country's CPI, evolves as $P_{t}^{1-\sigma_{f}}=\left(1-\alpha_{f}\right) \tilde{P}_{t}^{1-\sigma_{f}}+\alpha_{f} P_{t-1}^{1-\sigma_{f}}$.

\footnotetext{
${ }^{6}$ The monopoly power of firms causes them to optimally choose an inefficiently low level of output, a distortion which is present in most New Keynesian models and can be offset by a government subsidy. The availability of such an additional (fiscal) policy tool might have a slight impact on the trade-offs faced by the monetary policy; we do not explore this scenario in the present paper.
} 


\subsection{Households}

There is a continuum of households in the home country, indexed by $h$ on the interval $[0, M]$. Each household chooses consumption, wages, capital investment and a portfolio of assets to maximize its expected lifetime utility

$$
U_{t}=E_{t} \sum_{j=t}^{\infty} \beta^{j-t}\left\{\frac{\left[C_{j}(h)\right]^{1-\Theta}}{1-\Theta}-\frac{\left[L_{j}(h)\right]^{1+\chi}}{1+\chi}\right\}
$$

Each household supplies a differentiated labor service to all home intermediate goods producers and enjoys a degree of monopolistic power in setting the wage $W_{t}(h)$. Wages are sticky, and in any given period a household resets its wage with the probability $\left(1-\alpha_{w}\right)$.

Home households have access to two assets: domestically traded, zero net supply state-contingent bonds $D_{t}$ (which enable them to perfectly risk-share nationally), and a one-period international zero-net-supply bond $A_{t}$, denominated in foreign currency with nominal interest rate $i_{t}^{*}$. In the presence of the complete set of Arrow securities $D_{t}$, the bond is redundant for the purposes of national risk-sharing; we introduce it to model the dynamics of international debt. To motivate the need for international borrowing, we assume that home consumers discount the future more heavily than their foreign counterparts do, so that $\beta<\beta^{*}$. This assumption can be supported by appealing to international demographic differences: older countries, such as Germany or Japan, tend to be net savers, whereas younger countries, such as India or Mexico, typically have non-zero international debt; see Lane and Milesi-Ferretti (2001) for empirical evidence. We furthermore assume that when borrowing from abroad, home households must pay a risk premium $\varphi_{t}$, which depends on the home country's aggregate position in the international asset market:

$$
\varphi_{t}=\exp \left\{\xi\left(\frac{N F D_{t}}{4 P_{H, t} Y_{H, t}}-\kappa\right)\right\}-1
$$

The parameter $\xi$ measures the responsiveness of risk premium to changes in the ratio of home country's aggregate international debt level $N F D_{t}$ (defined below) to annualized output (since each period in the model is calibrated to represent one quarter), and $\kappa$ is a shift parameter that allows us to change the steadystate value of the debt. ${ }^{7}$ This parameter can be thought of as a measure of trustworthiness of a country:

\footnotetext{
${ }^{7}$ To change the steady-state debt-to-GDP ratio, we could alternatively adjust the responsiveness parameter $\xi$; however, that would muddle the comparison of capital flow dynamics across different calibrations since the cost of international borrowing would be changing simultaneously with the overall debt level.
} 
a higher value of $\kappa$ means that the economy can sustain larger levels of foreign debt without having to pay a higher risk premium. Each home household takes the cost of borrowing $\varphi_{t}$ as exogenous; the risk premium payments are distributed evenly to foreign households. ${ }^{8}$ By combining the log-linearized versions of the household's first order conditions with respect to its asset holdings, we obtain a modified version of the uncovered interest parity (UIP) condition:

$$
i_{t}-i_{t}^{*}=E_{t} \Delta s_{t+1}+\varphi_{t}
$$

which now includes the effect of the home country's net foreign asset position on the risk premium, and where $i_{t}$ and $i_{t}^{*}$ are the yields on home and foreign one-period nominal risk-free bonds.

Households pay lump-sum taxes to the government and receive profits of domestic firms. Capital accumulation is subject to quadratic adjustment costs.

\subsection{The Government}

The above modeling assumptions give rise to a number of distortions. The traditional closed-economy inefficiencies arise due to sticky prices and monopoly power of firms. The open economy framework adds to these three more distortions: sticky prices inhibit expenditure switching, incomplete financial markets lower the degree of international risk sharing, while imperfect substitutability between home and foreign goods generates a terms-of-trade externality. The optimal targeting rule of the central bank that wishes to maximize domestic consumer welfare in the this framework has been well studied in the literature, and typically includes three quadratic terms: domestic inflation (to offset the inefficient production allocation due to sticky prices), the real exchange rate or the terms of trade (to allow for expenditure-switching following asymmetric productivity shocks and to exploit the terms of trade externality), and output or consumption gap (to promote complete risk sharing), with the coefficients on each term being given by complex functions

\footnotetext{
${ }^{8}$ Other ways of modeling international bonds either assume that countries incur quadratic costs of deviating from an exogenously specified international asset position (Demirel, 2009; Wang, 2010; Rabitsch, 2012), or define risk premium as a linearly decreasing function of net foreign wealth while setting $\beta=\beta^{*}$ (Benigno and Thoenissen, 2008; De Paoli, 2009b; Selaive and Tuesta, 2003). Both of these approaches are unsatisfactory: the former penalizes countries for repaying their debts, while the latter can lead to situations in which home consumers can borrow from abroad at lower rates than foreigners themselves can (when home country's net foreign wealth improves relative to the steady-state level).
} 
of the underlying structural parameters of the model. ${ }^{9}$

Taking this theoretical result as given, we instead focus on simple policy rules in which the interest rate is set in response to fluctuations in inflation and/or the real exchange rate. ${ }^{10}$ Our motivation for doing so is two-fold. First, the optimal targeting rule may be difficult to implement since it requires policy makers to monitor unobservable shocks and to estimate the necessary structural parameters of the economy. Second, we believe that our approach corresponds much closer to the actual practice of modern central banks and thus is better suited for policy analysis.

As a baseline, we assume that the Home central bank follows a variation of the Taylor rule commonly used in monetary literature:

$$
i_{t}=\left(1-\rho_{i}\right) \bar{\imath}+\rho_{i} i_{t-1}+\left(1-\rho_{i}\right)\left[\rho_{\pi} \pi_{t}+\rho_{q} \Delta q_{t}\right]
$$

Here $\bar{i}=\frac{1}{\beta}-1$ is the steady state level of the domestic interest rate, $\pi_{t} \equiv \frac{P_{t}}{P_{t-1}}$ is the home CPI inflation, $q_{t} \equiv$ $\ln \left(\frac{S_{t} P_{t}^{*}}{P_{t}}\right)$ is the $\log$ of the real exchange rate, and the parameters $\rho_{\pi}$ and $\rho_{q}$ are optimally chosen by the monetary authority. We assume that persistence in the conduct of monetary policy $\left(\rho_{i}>0\right)$ is a primitive feature of the economy. In a forward-looking model, higher interest rate persistence means that stabilization (of inflation, output, exchange rate or any other target of the central bank) requires a much smaller movement of the time- $t$ interest rate, since such movement is expected to prevail far into the future. Lower variability of interest rates, in turn, implies lower volatility of consumption, output, and labor effort, and thus higher consumer welfare. This result has been discussed in great detail in Woodford (1999), and has also been reported more recently by Senay (2008).

In addition to the Taylor rule, we also consider three strict targeting rules that have been widely discussed in the literature: PPI targeting (traditional prescription for a closed economy and for some fairly restrictive versions of open economy models), CPI targeting, and a nominal exchange rate peg. We solve the model

\footnotetext{
${ }^{9}$ See Benigno (2009), De Paoli (2009), and Corsetti, Dedola, and Leduc (2010) for the details of the derivation of optimal targeting rules.

${ }^{10} \mathrm{We}$ omit the output gap term because the mandates of many central banks are vague on the importance of output targeting; the European Central Bank, for example, focuses exclusively on short and medium term inflation. Additionally, the computational time of searching over a grid of possible parameter values is significantly reduced. The real exchange rate term can be used instead to increase the degree of risk sharing.
} 
numerically and search for the monetary policy that maximizes the expected utility of home households given the rest of the model's parameter values and the processes for the technology shocks.

Below we focus on the case of a small open economy, in which it is not unreasonable to assume that the home central bank cannot influence the behavior of policymakers in large countries. ${ }^{11}$ Therefore, we do not address the question of monetary policy cooperation. Instead, we assume that the monetary authority of the Foreign country credibly targets local CPI inflation (so that $\pi_{t}^{*}=0$ at all times), and look for the welfare-maximizing rule that can be adopted by the central bank of the Home country.

Finally, to bring the GDP decomposition of the model in line with the data, we assume that government purchases $G_{t}$ and $G_{t}^{*}$ account for a fifth of total output; both governments balance their budgets every period, so $G_{T, t}=T_{t}$ and $G_{T, t}^{*}=T_{t}^{*}$.

\subsection{Equilibrium}

Equilibrium in the economy is defined by goods and asset market clearing conditions, budget constraints, and the first order conditions of home and foreign agents, given the form of monetary and fiscal policy rules described above and the stochastic processes for the shocks $\left\{\varepsilon_{t}^{z}\right\}$ and $\left\{\varepsilon_{t}^{z *}\right\}$. Solution to the model is found using perturbation methods described in Schmitt-Grohé and Uribe (2004) and Collard and Juillard (2001); computer code is written in Dynare (Collard and Juillard, 2003). Second order approximations were used to compute moments, value functions, and impulse response functions presented below.

By combining the aggregate budget constraint of home households with aggregate profits of home firms and the government constraint $G_{T, t}=T_{t}$, we obtain the law of motion for Home country's nominal international liabilities (net foreign debt),

$$
\begin{aligned}
N F D_{t} & =\left(1+i_{t-1}^{*}+\varphi_{t-1}\right) N F D_{t-1} \Delta S_{t}- \\
& \left\{P_{H, t} M^{*}\left[C_{H, t}^{*}+I_{H, t}^{*}+G_{H, t}^{*}\right]-S_{t} P_{F, t}^{*} M\left[C_{F, t}+I_{F, t}+G_{F, t}\right]\right\},
\end{aligned}
$$

where the first term measures the current value, inclusive of interest payments, of last period's debt and the second term represents the balance of trade. Current account balance, $C A_{t}$, is equal to the trade balance

\footnotetext{
${ }^{11}$ The issue of monetary policy cooperation between large interdependent economies has been address in, among others, Benigno and Benigno (2006), Corsetti and Pesenti (2005), Obstfeld and Rogoff (2002), and Rabitsch (2012).
} 
less the interest payments on outstanding debt, $\left(i_{t-1}^{*}+\varphi_{t-1}\right) N F D_{t-1} \Delta S_{t}$.

\subsection{Measure of National Welfare}

We define the value function that measures aggregate welfare of the home country as

$$
V_{t}=\max E_{t} \sum_{j=t}^{\infty} \beta^{j-t}\left\{\frac{M C_{j}^{1-\Theta}}{1-\Theta}-\frac{A L_{j}}{1+\chi}\right\},
$$

where $A L_{j} \equiv \int_{0}^{M} L_{j}(h)^{1+\chi} d h$ measures the aggregate disutility of work. This function will allow us to make quantifiable comparisons of consumer welfare across different specifications of the model. Suppose, for example, that $V_{t}^{1}$ and $V_{t}^{2}$ measure household welfare for monetary policy parameter values $\left\{\rho_{\pi}^{1}, \rho_{q}^{1}\right\}$ and $\left\{\rho_{\pi}^{2}, \rho_{q}^{2}\right\}$, respectively. In the case of $\log$ utility, the difference between the two value functions,

$$
\epsilon=V_{t}^{1}-V_{t}^{2}
$$

can be interpreted as cost, expressed as percent of consumption, of moving away from policy $\left\{\rho_{\pi}^{1}, \rho_{q}^{1}\right\}$ to policy $\left\{\rho_{\pi}^{2}, \rho_{q}^{2}\right\}$.

Expression (10) measures conditional welfare, which depends on the state of the economy at time $t$. Following Collard and Juillard (2001) and Schmitt-Grohé and Uribe (2004), we assume that at time $t$ the economy is in the deterministic steady state and compute second-order approximation of the welfare function. The alternative approach to policy analysis would be to measure unconditional welfare by integrating out the initial state of nature. However, as pointed out in Kim et al. (2008), unconditional welfare measure ignores transitional effects while the economy moves from the initial steady state to the one implied by a particular policy choice, and therefore can produce spurious performance reversals. ${ }^{12}$

\section{The Impact of Foreign Debt on Consumption Risk Sharing}

Mykhaylova and Staveley-O'Carroll (2014) show that, in the above setup, high levels of foreign-currency denominated debt can alter the cross-border transmission of productivity shocks and significantly lower the

\footnotetext{
${ }^{12}$ The arguments of Kim et al. (2008) notwithstanding, we have performed a robustness check by repeating all the exercises below using unconditional welfare measure. Our results - in both the magnitude and the sign of welfare differences-remain virtually unchanged.
} 
degree of consumption risk sharing between home and foreign households. Once again, we refer the interested reader to the original paper for the derivations of the transmission mechanisms, and below summarize the main findings of the paper.

Under the assumption of complete asset markets, perfect cross-country risk sharing occurs via portfolio selection regardless of the RER fluctuations. When financial markets are incomplete, home and foreign households can share risk also via the movement of international prices, as pointed out in Cole and Obstfeld (1991). More strongly, in our model the only internationally traded asset has non-state-contingent payouts, which means that the RER movements are the only mechanism of international risk sharing. Consider the adjustment of the world economy to a temporary increase in $Z_{t}$, which creates two distinct effects: an increase in supply due to higher productivity, and an increase in demand for the home good as home consumers become wealthier. Depending on which of these two effects dominates, the resulting price movement may transfer the benefits of higher home productivity to the foreign consumers (when the RER depreciates) or keep the benefits in the home country (following a RER appreciation). In the absence of international debt and under most standard calibrations, the supply effect dominates; therefore, in order to shift global demand to the more plentiful home goods the real exchange rate depreciates. This depreciation transfers a part of the home wealth effect abroad and causes an increase in foreign consumption and GDP.

Foreign debt works to strengthen the demand effect. We separate the effect of debt on the home economy into two channels: risk premium and debt valuation. To elucidate the first channel, we substitute the expressions for the two countries' CPIs and the definition of TOT $\tau_{t} \equiv \frac{S_{t} P_{F, t}^{*}}{P_{H, t}}$ into (6) and log-linearize the result to obtain the following reduced-form relationship between the risk premium, debt, output, and TOT:

$$
\hat{\varphi}_{t} \cong \frac{\xi \kappa}{\bar{\varphi}}(\hat{d}_{t}+\underbrace{\mu^{*} \hat{\tau}_{t}}_{\text {TOT effect }}-\underbrace{\hat{y}_{H, t}}_{\mathrm{RP} \text { channel }})
$$

Here hats over lowercase letters denote log deviations of variables from their steady state, and bars indicate steady-state values. The first term in the parentheses, $\hat{d}_{t}$, captures the direct impact of the real debt level on the risk premium. ${ }^{13}$ The second term shows the effect of terms of trade on the value of existing debt and, consequently, on the price of foreign borrowing; we describe this channel in more detail below. We define

\footnotetext{
${ }^{13} \mathrm{Log}$-linearizing the model equations gets rid of the convex relationship between the risk premium and foreign debt. Allowing for a nonlinearity in (12) would work to strengthen our findings.
} 
the risk premium $(R P)$ channel as the change in $\hat{\varphi}_{t}$ resulting from movements in home output $Y_{H, t}$.

Due to the presence of original sin, an improvement (deterioration) of the TOT triggers the debt valuation (DV) channel, as the real value of foreign debt falls (rises), making the home country richer (poorer) and therefore amplifying (muting) the business cycle:

$$
\begin{aligned}
& \hat{d}_{t} \cong \hat{\imath}_{t-1}^{*}+\bar{\varphi} \hat{\varphi}_{t-1}+(1+\bar{\imath})\left(\hat{d}_{t-1}-\pi_{t}^{*}\right)+\underbrace{\bar{\imath} \mu^{*} \hat{\tau}_{t}}_{\text {DV channel }}+ \\
& \frac{1}{\kappa} \underbrace{\left[\bar{\tau} \frac{\bar{Y}_{F}}{\bar{Y}}\left(\hat{\tau}_{t}+\hat{y}_{F, t}\right)-\frac{\bar{Y}_{H}^{*}}{\bar{Y}} \hat{y}_{H, t}^{*}\right]}_{\text {Balance of trade effect }} .
\end{aligned}
$$

This last expression comes from substituting the definition of TOT into the log-linearized version of (9).

Following an increase in home output due to a technological improvement, the now lower debt-to-GDP ratio causes a decline in the risk premium (6). Intertemporal optimization in the face of this lower price of borrowing causes home households to increase current period consumption. Moreover, since interest payments on their debt have decreased, the resulting positive income effect causes an increase in the entire consumption profile, both current and future. The resulting unambiguous increase in current demand works to (at least partially) reverse the RER depreciation of the standard model. This risk premium mechanism by itself is not strong enough to completely overcome the effect of the increased supply of the home good on international prices. However, two additional features of our model —original sin and a high level of foreign debt - can strengthen the demand effect. The debt valuation mechanism operates via real exchange rate movements, which (depending on the magnitude of the home country's indebtedness) can generate significant changes in the international debt burden of the home households.

The combination of these two channels generates a positive feedback loop that works against the baseline RER depreciation. Once the risk premium channel increases home demand, the RER appreciates relative to the no-debt scenario. This small improvement in the RER drives down the value of foreign debt, which leads to a fall in the risk premium, further appreciating the real exchange rate and creating a self-reinforcing loop. For a very high steady-state NFDR (close to 1), this interaction can overturn the supply effect of productivity on RER, and the latter actually appreciates. Existence of debt can thus produce a negative comovement between RER and relative consumptions and therefore lower the degree of cross-country risk sharing. International price movement not only fails to transfer wealth to foreign households, but instead 
further amplifies the effect of the productivity shock on the home economy.

Following an improvement in foreign productivity, the risk premium channel is not operational in the first few periods after the shock (since home output does not change on impact); consequently, home consumers' international borrowing constraint remains unchanged. However, the RER appreciation lowers the real value of the Home country's outstanding debt through the debt valuation channel; as before, the feedback mechanism lowers the risk premium on foreign borrowing in response to falling real debt level at home. As the value of foreign consumers' assets declines, some of the foreign wealth effect is transferred to home households. As a result, home consumption goes up relative to that of foreign households. For very high steady-state debt levels, we again observe a negative comovement between the RER and the relative consumption $C / C^{*}$.

In the rest of the paper, we turn our attention to the advisability of real exchange rate targeting by the central bank given the dampening effect of debt on international risk sharing.

\section{Optimal Monetary Policy in the Presense of Foreign Debt}

\subsection{Calibration and Business Cycle Properties}

The parameter values used in the model calibration are described in Table 1. Our goal is to calibrate the model so that its results are not country-specific; however, if the literature suggests a range of values for any given parameter, we set it to reproduce the average outcomes in Central and Eastern European Countries (CEECs), all of which can be classified as small open economies with varying levels of foreign-currency denominated debt levels. ${ }^{14}$ To this end, we set the relative country size ratio, $M: M^{*}$, at $1: 19$, based on the average relative size of these sample economies vis-à-vis EU-27, their main trading partner (as per statistics in World Trade Organization trade profiles). The advantage of using a two-country model rather than a small open economy framework is the ability of the former to capture non-trivial spillovers between the two economies, as pointed out in, among others, Mykhaylova (2011). We also perform several robustness checks to make the results applicable to a wider range of countries. Unless otherwise indicated, all parameters describing the Foreign economy are identical to the ones in the Home country.

\footnotetext{
${ }^{14}$ Appendix B presents a detailed description of the data used in the calibration.
} 
The first set of parameters, which are standard in the monetary/business cycle literature, includes the foreign discount factor $\beta^{*}$; the relative risk aversion $\Theta$; the share of capital in production $\nu$; and the degree of price rigidity in the final goods market $\alpha_{f}$. We set these parameters equal to $0.99,1,0.33$, and 0.75 , respectively.

The value of Frisch labor elasticity, $\chi^{-1}$, used in RBC models ranges between 0.13 in, for example, Christiano et al. (2011), and 1 in Adolfson et al. (2007); however, Canzoneri et al. (2007) find that its value does not matter much for the ability of the model to fit the data. We take the middle road and set $\chi^{-1}=1 / 3$. We set $\mu$, the home bias parameter, to 0.75 to match the average import-to-GDP ratio of 25 percent. Foreign home bias $\mu^{*}$ is adjusted upward to 0.99 , so that imports constitute a smaller share of foreign consumption. In the absence of this adjustment, foreign country would demand a disproportionately large share of home country output. ${ }^{15}$ We follow Chari, Kehoe and McGrattan (2002) in setting the trade elasticity parameter $\eta$ equal to 1.5. This, in conjunction with the assumed log-utility of consumption, implies that home and foreign bundles in (3) are substitutes. However, since the dynamics of many key variables hinge critically on the value of trade elasticity, we check the robustness of our results by also setting $\eta$ to values below unity.

We use data from several geographical regions to calibrate the home economy discount factor. In Central and Eastern European countries (CEECs), the annualized spreads between LIBOR rates and central bank lending rates range from 0.3 percent for Slovakia to 24.1 percent for Poland during the 1993-2011 period. Bouvatier (2007) estimates risk premia on 3-month borrowing rates in several Asian countries to lie in the 3-5 percent range during the mid-1990s. Elekgad et al. (2006) use Bayesian techniques to find that an annual risk premium of at least 8 percent applied to Korean borrowing from abroad during the 1990-2003 period. Based on this information, we set $\beta=0.97$, resulting in an 8.5 percent annualized spread between the two model economies' steady-state interest rates. ${ }^{16}$ The functional form of the risk premium is a modified

\footnotetext{
${ }^{15}$ The relationship between the two home biases and the relative country sizes can be expressed as $\mu^{*}=1-(1-\mu) M / M^{*}$.

${ }^{16}$ To justify the existence of foreign debt, we can assume that the home economy is either more impatient $\left(\beta<\beta^{*}\right)$ or more credit-worthy than other countries (captured in our model by the parameter $\kappa$ ). Mechanically, we can turn these two channels on and off independently of one another; in the paper, we assume the more sensible interpretation of debt accumulation due to the difference in discount factors. However, after checking the robustness of our findings by letting $\beta=\beta^{*}$, we find that the main results of the paper are virtually unaffected by this change.
} 
version of the one used in Christiano et al. (2011) and Eicher et al. (2008). The cost of participating in the international asset markets, $\xi$, is set to 2 . Given the steady-state interest rates at home and abroad (which, in turn, are determined by the parameters $\beta$ and $\beta^{*}$ ), setting $\xi=3$ helps us to match the empirical moments of the current account dynamics in CEECs. In the rest of the paper, we keep the value of $\xi$ fixed and vary the shifting parameter $\kappa$ (see equation 6 ) to achieve two different steady-state debt-to-GDP ratios: $0 \%$ and $100 \%$, with the first calibration roughly corresponding to Albania and Russia, and the last capturing the macroeconomic conditions, among many others, in Hungary and Iceland during the 2000-2007 period. ${ }^{17}$ We have also tested the intermediate case by setting the debt-to-GDP ratio to $50 \%$, which we omit from the tables below for space considerations; these results are available from authors upon request.

Empirical estimates such as Bils and Klenow (2004) and Nakamura and Steinsson (2008) suggest that the duration of price stickiness in the finished goods sectors is longer than for intermediate goods producers; based on the results reported in the second paper, we set $\alpha_{i n t}=0.5$, implying a 6 -month average duration of price contracts. As in Devereux and Engel (2007), price markups in both intermediate and final goods sectors, $\sigma_{i n t}$ and $\sigma_{f}$, are set to 6, resulting in a 20 percent profit margin. Following Adolfson et al. (2007), we set the degree of wage stickiness to $\alpha_{w}=0.70$, and the elasticity of substitution between labor varieties $\sigma_{l}=20$.

We set the ratio of government purchases to GDP equal to 20 percent, in line with the data. Calibration of productivity process is borrowed from Chari, Kehoe and McGrattan (2002), with $Z_{11}=Z_{22}=0.95$, $Z_{12}=Z_{21}=0, \operatorname{Var}\left(\varepsilon_{z}\right)=\operatorname{Var}\left(\varepsilon_{z}^{*}\right)=4.9 \times 10^{-5}$, and $\operatorname{Cov}\left(\varepsilon_{z}, \varepsilon_{z}^{*}\right)=1.2 \times 10^{-5}$. We use the estimates reported in Wesche (2003) to set the interest rate inertia $\rho_{i}=0.9$.

To keep the results widely applicable, we compare the model's performance against the range of empirical moments calculated for several CEECs. The benchmark parameter values result in the following decomposition of steady state GDP (in both countries): consumption share of $62 \%$, investment share of $18 \%$ and government spending share of 20\%; the corresponding European averages for the 1980-2011 period range between $51 \%-63 \%, 19 \%-28 \%$, and $18 \%-22 \%$.

\footnotetext{
${ }^{17}$ It is likely that countries with higher levels of debt face steeper interest rate schedules when borrowing in the international markets. We hold the value of $\xi$ constant regardless of the NFDR to isolate the effects of foreign borrowing on the transmission of productivity shocks.
} 
Business cycle properties of the model for the benchmark calibration are presented in Table 2. The variances of the simulated variables for $N F D R=0$ are somewhat lower than the empirical counterparts, partly due to the fact that the model dynamics are driven only by productivity shocks; the autocorrelations, however, fall comfortably in the empirical range. The version of the model with non-zero NFDR is much better at matching the data.

\subsection{Optimal Exchange Rate Policy}

We search for parameterization of policy rule (8) that maximizes the expected lifetime utility of domestic households; more specifically, we perform a grid search over $[1.1,3]$ for $\rho_{\pi}$ and $[0,2]$ for $\rho_{q}$ in steps of 0.1. ${ }^{18}$ We also calculate consumer welfare for the three strict targeting rules: PPI, CPI, and PEG. For each specification under consideration, we then study the impact of international asset holdings on the welfare-maximizing choice of the monetary policy rule.

In the version of the model without nominal rigidities $\left(\alpha_{i n t}=\alpha_{f}=\alpha_{w}=0\right)$, prices adjust immediately following any shock to achieve desirable levels and compositions of home and foreign output. In this case, the choice of the exchange rate regime is irrelevant, as argued in Friedman (1953). Indeed, our simulations indicate that the level of welfare and the degree of risk sharing are virtually independent of the monetary policy rule. In the rest of the paper we therefore focus on the scenario in which prices and wages are sticky.

Figure 1 summarizes the results of our baseline Taylor rule parameter grid computations; welfare gains/losses shown in the figure are computed relative to the starting point on the grid, $\left\{\rho_{\pi}, \rho_{q}\right\}=\{1.1,0\}$. Further, panel A of Table 3 compares the performance of the optimal Taylor rule with the other three policy options; the table reports welfare gains of pursuing a particular monetary rule relative to the policy of complete domestic price stabilization (PPI targeting). The first finding that emerges from examining the numbers in columns (I) suggests that economies with no foreign debt do not benefit from real exchange rate stabilization; on the other hand, central banks of heavily indebted countries can increase their aggregate consumer welfare by responding to RER fluctuations. In countries with no steady state holdings of debt, fixing the nominal exchange rate actually leads to welfare loss equal to 0.1 percent of steady state consumption. However, once

\footnotetext{
${ }^{18}$ According to the Taylor principle, the central bank should raise nominal interest rates more than one-for-one in response to inflation increases, so that $\rho_{\pi}>1$; see Taylor (1999) for further discussion.
} 

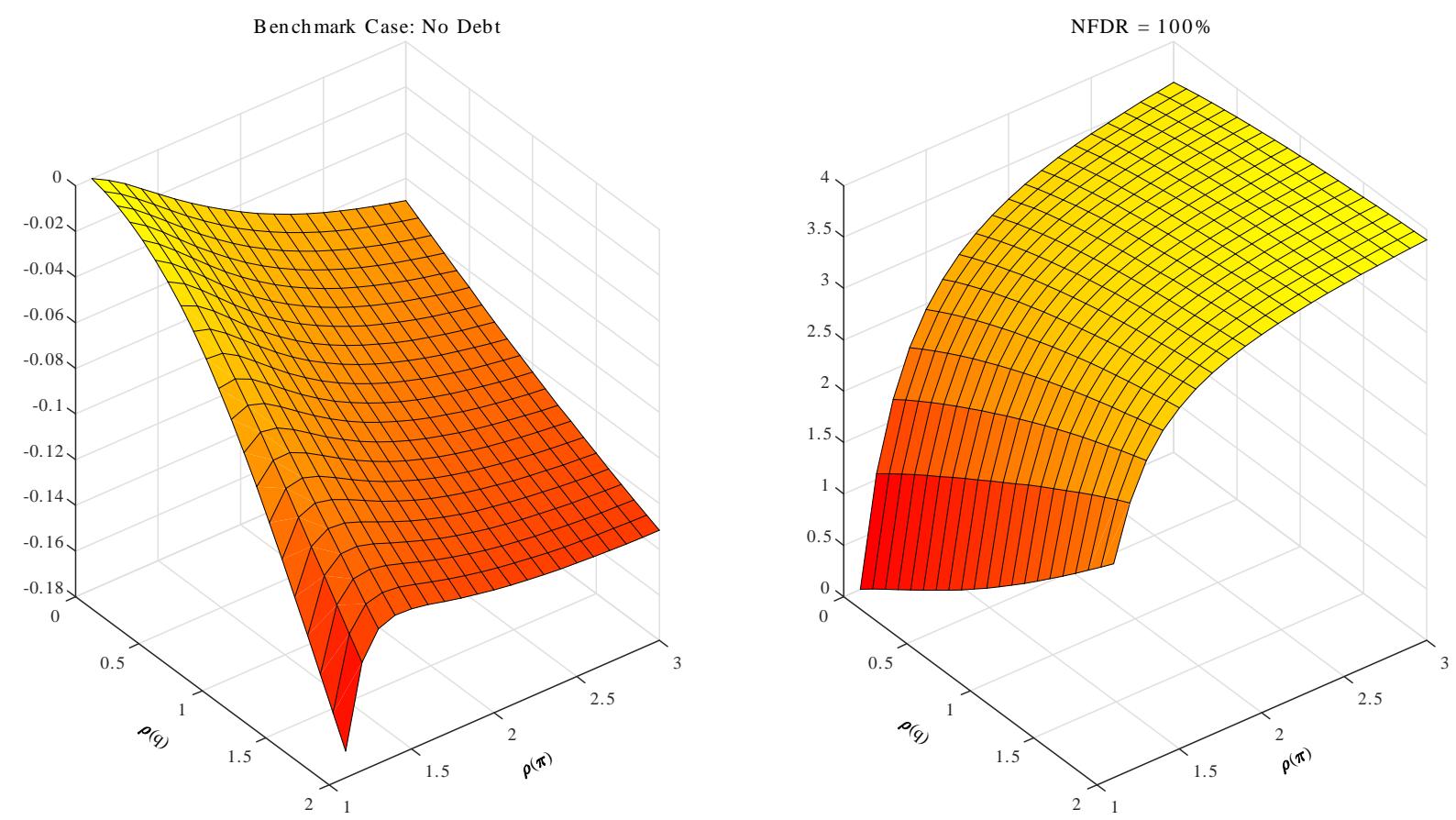

Figure 1: Welfare gains, measured in percent of steady state consumption, relative to the benchmark Taylor rule specification $\left\{\rho_{\pi}, \rho_{q}\right\}=\{1.1,0\}$.

the NFDR increases to 100 percent, strict exchange rate stabilization becomes optimal, improving welfare by 0.25 percent of consumption.

To understand the forces behind this prescription, it is important to recall the monetary policy objectives specific to an open economy setting and then to study the impact of foreign indebtedness on their relative importance in the ultimate choice of the policy regime. Consider the case of a positive shock to home productivity, shown in Figure 2, and start with the left panel that corresponds to zero steady state debt. On the one hand, the central bank wants to engineer an exchange rate depreciation to shift the global demand towards the more plentiful home good (ES). Additionally, a depreciated exchange rate helps to shift some of the positive wealth effect from the home to the foreign households (RS). On the other hand, an appreciated domestic currency increases the purchasing power of home households, and can be welfare-improving as long as they can easily substitute foreign for home goods and thus lower their labor effort (TE). The winning policy in this tug-of-war depends on the relative magnitudes of these three forces.

Panels B and C of Table 3 compare the degree of risk sharing and of expenditure switching (which we 
measure as the correlation between the relative level of home productivity and the level of its real exchange rate) obtained under the different policy regimes. For $N F D R=0$, both correlations are very high for all possible policy rules considered in our paper: the range of risk sharing is given by $[0.8825,0.9669]$, whereas the degree of expenditure switching varies between 0.8015 and 0.9977 . Since the size of any possible RS and ES gains from switching policies is small, the central bank can work to increase consumer welfare through other channels. A RER appreciation generated by following the optimal Taylor rule reduces labor effort relative to the other three policies and so achieves the highest level of welfare under the baseline parameter configuration, albeit by sacrificing some measure of risk sharing - in fact, the lowest value of $\operatorname{Corr}\left(C / C^{*}, Q\right)$ corresponds to the optimal Taylor rule.
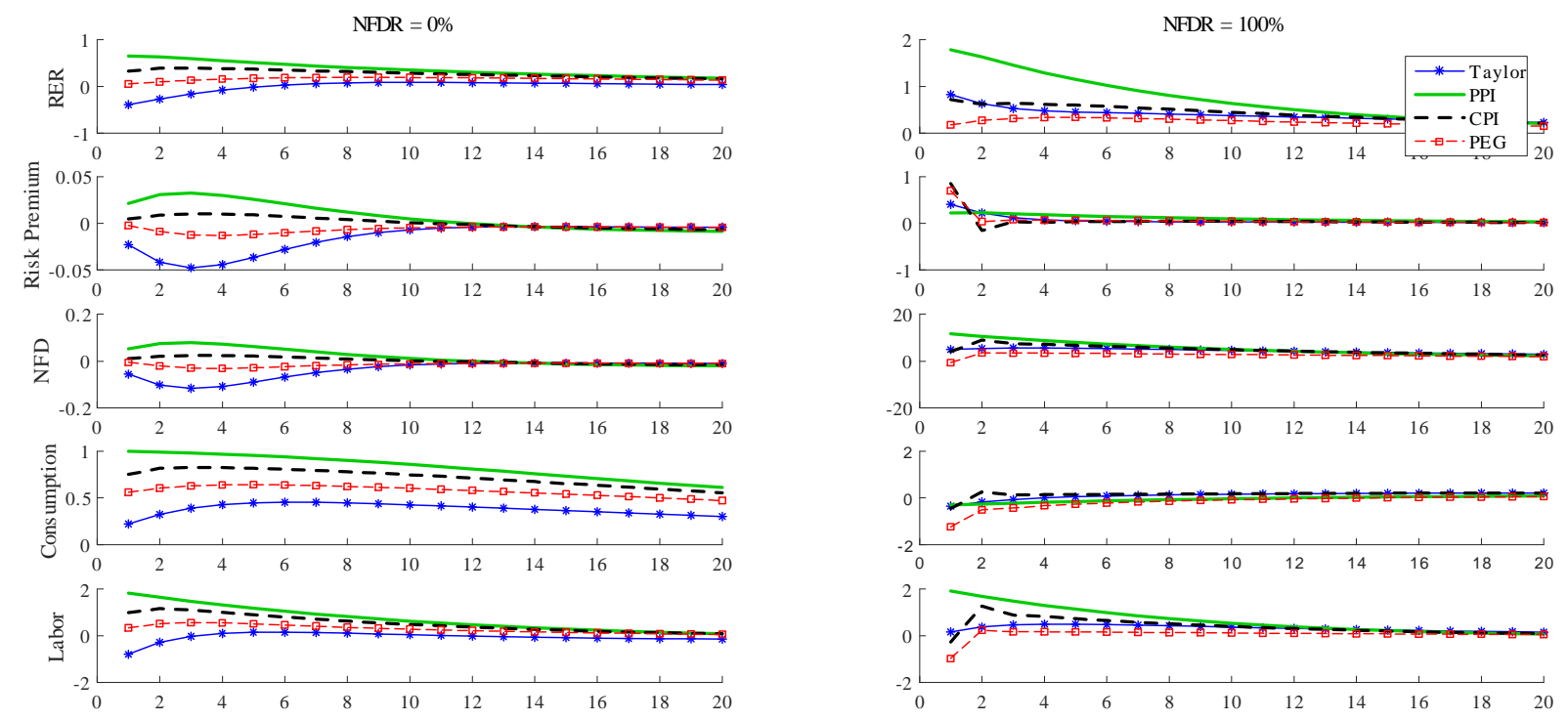

Figure 2: Impact of monetary policy choice on the model dynamics following a positive shock to home productivity. In both panels, we set the Taylor rule parameters to their optimal levels: $\left(\rho_{\pi}, \rho_{q}\right)=(1.1,0)$ for $N F D R=0$, and $(3.0,2.0)$ when $N F D R=1$. Vertical axis shows percent deviations of variables from their steady-state values.

How does the Taylor rule deliver the necessary RER appreciation? It is useful to compare the corresponding impulse response functions to those produced under PPI. In the latter case, since the home price of the now more plentiful good is not allowed to adjust, the real exchange rate must depreciate to tilt global demand to the home products. On the other hand, under the policy of (very loose) CPI targeting, home prices do decline, although gradually. Instead, the positive wealth effect, experienced by the home consumers, 
appreciates the real exchange rate and with it the terms of trade.

Following an improvement in foreign productivity (Figure 3), foreign prices should optimally fall, and the real exchange rate should appreciate from the home country's perspective (ES). Appreciation also lowers the work effort of home households, which improves welfare given the very high degree of risk sharing at low levels of debt (TE). Finally, given the falling home-foreign consumption gap, appreciation also delivers a high degree of risk sharing (RS) by improving the purchasing power of home households and increasing the value of their net international assets (notice that appreciation causes NFD to turn negative in the left panel of Figure 3). Thus, all three policy objectives are aligned, and allowing for full RER flexibility is therefore the best policy prescription (notice from the figure that PPI and Taylor achieve very similar economic outcomes, whereas CPI and PEG, both of which place more emphasis on real exchange rate control, deliver a suboptimal response of international prices).

High levels of foreign debt (right panels of Figures 2 and 3) change the relative importance of the risksharing objective by exaggerating the extent of wealth transfer between home and foreign households via the valuation effect of the RER movement and the corresponding change in the risk premium on foreign borrowing. The result is a much lower degree of risk sharing under certain monetary policy rules: notice that the set of possible consumption-RER correlations now covers the $[-0.7722,0.6390]$ interval. ${ }^{19}$ More specifically, an exchange rate depreciation following an improvement in home productivity now carries an additional cost of significantly increasing the debt burden of home households. For example, under the policy that allows for the sharpest RER depreciation-Taylor rule with $\left(\rho_{\pi}, \rho_{q}\right)=(1.1,0)$ - the debt-to-GDP ratio increases to 120 percent, and the degree of risk sharing falls to -0.7120 as most of the wealth effect is transferred abroad. ${ }^{20}$ Conversely, a RER appreciation following an increase in $Z^{*}$ would disproportionally

\footnotetext{
${ }^{19}$ For each model specification, we consider $3+21 \times 20=423$ possible policy choices. Table 3 reports results for only four of these (including the best of the 420 considered Taylor rules). Thus, the full range of the possible correlations may be wider than reported in the table.

${ }^{20} \mathrm{An}$ observant reader will notice a discrepancy between the RER response shown in the right panel of Figure 2 (depreciation) and that described in Section 3 (appreciation). The difference stems from a change in the relative size of the home economy: $M=M^{*}=1$ in Mykhaylova and Staveley-O'Carroll (2014) versus $M=1$ and $M^{*}=19$ in the present paper. In the SOE calibration, the foreign CPI is almost completely insulated from fluctuations in the price of home country goods. Following an increase in $Z_{t}$, a decrease in $i_{t}$ is therefore not accompanied by a decrease in $i_{t}^{*}$, and the exchange rate unambiguously
} 
benefit home rather than foreign households through a fall in the foreign indebtedness of the former.
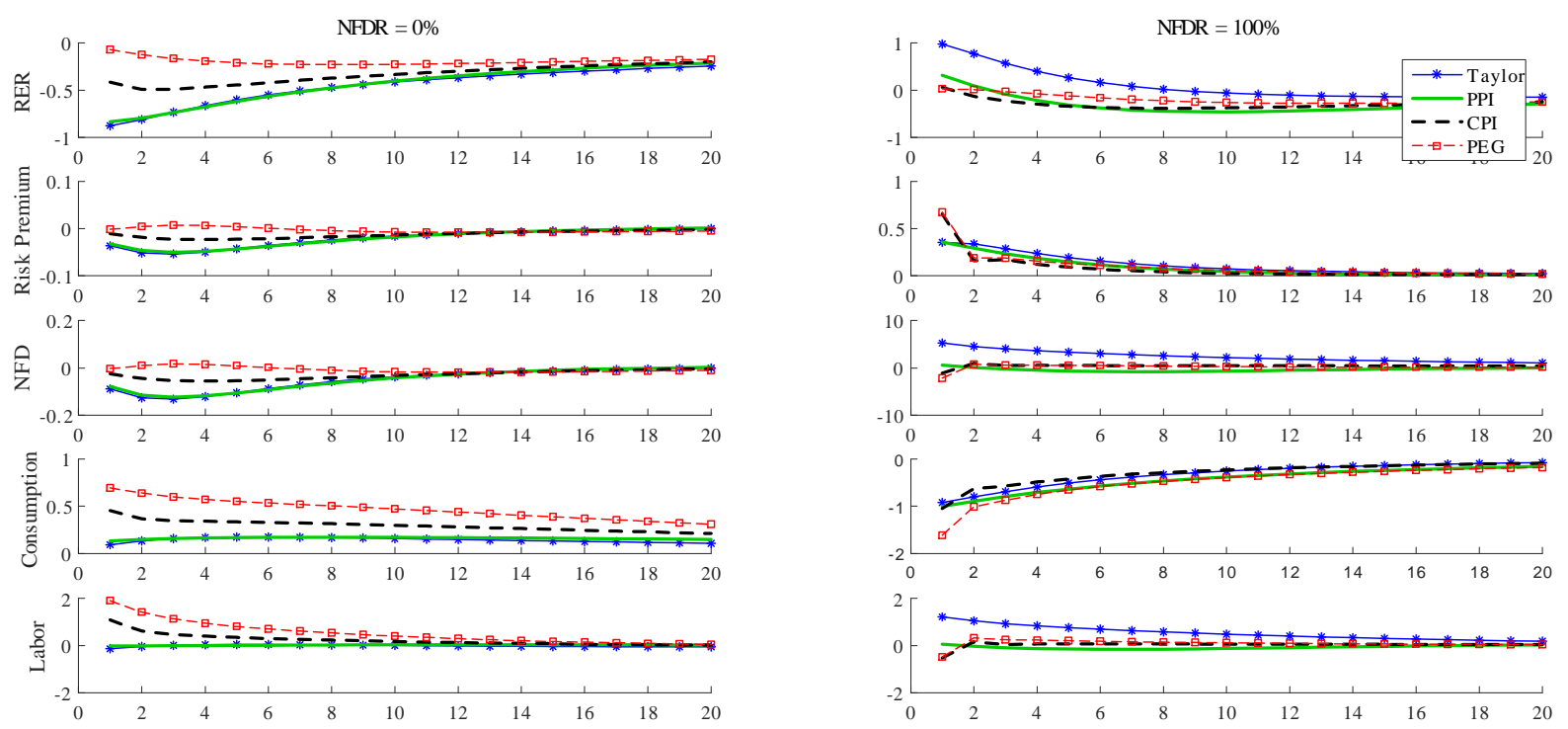

Figure 3: Impact of monetary policy choice on the model dynamics following a positive shock to foreign productivity.

In both panels, we set the Taylor rule parameters to their optimal levels: $\left(\rho_{\pi}, \rho_{q}\right)=(1.1,0)$ for $N F D R=0$, and $(3.0,2.0)$ when $N F D R=1$. Vertical axis shows percent deviations of variables from their steady-state values.

We find that focusing on the RS objective delivers greater welfare gains when debt is high than pursuing the other two open economy inefficiencies. Since improving the degree of risk sharing calls for RER stabilization, the central bank should aggressively target the exchange rate to reduce the fluctuations of the debt level following both shocks. Our simulations indicate that a policy of strict exchange rate targeting can improve home consumer welfare by 0.25 percent of steady state consumption.

\section{Sensitivity to Open Economy Features}

We now examine the robustness of the policy prescriptions in case that (a) the exchange rate pass-through is perfect, (b) imports and exports are complements, and (c) countries are more open to international trade, since all these parameters are likely to vary from one economy to another.

$\overline{\text { depreciates for any given level of the risk premium }} \varphi_{t}$ (see the UIP condition 7). Moreover, it can be shown that the effects of this depreciation on the values of the risk premium and the debt level are positively related to the size of the home bias $\mu^{*}$. 


\subsection{Exchange Rate Pass-Through}

The assumption that the retail sector prices imported goods in local currency shields consumers somewhat from the fluctuations in international prices. Insofar as the degree of the exchange rate pass-through governs the strength of the expenditure-switching mechanism, it is worthwhile taking a closer look at the effects of nominal rigidities on our results. Below we consider the following four price stickiness structures: (a) fully flexible prices, $\alpha_{i n t}=\alpha_{f}=0$; (b) $\alpha_{i n t}=0.5, \alpha_{f}=0$, which, in the context of our model, is equivalent to assuming producer (rather than local) currency pricing; (c) $\alpha_{i n t}=0, \alpha_{f}=0.75$, corresponding to a simpler version of local currency pricing; and (d) the baseline specification $\alpha_{i n t}=0.5, \alpha_{f}=0.75$. Nominal rigidities in the foreign economy are modeled symmetrically.

The extent of the exchange rate pass-through to consumer prices depends, of course, not only on the length of wholesale and retail price contracts, but also on the assumed form of the monetary policy response function. Figure 4 plots the impulse responses of several macroeconomic indicators following an improvement in home productivity when $N F D R=0$ for the three targeting rules. When the central bank stabilizes producer price inflation, the value of $\alpha_{i n t}$ is irrelevant for economic activity. Analogously, the degree of stickiness $\alpha_{f}$ in the retail sector has no impact on the impulse response functions under the policy of CPI stabilization. Fundamentally, however, economic activity remains qualitatively the same.

Nonetheless, we repeat the baseline simulations under the more standard assumption that price stickiness exists on the wholesale but not retail level (so that $\alpha_{i n t}=0.5$ and $\alpha_{f}=0$, implying a perfect exchange rate pass-through). In this calibration, ES and RS mechanisms, which operate through the adjustment of relative prices, are stronger. With no debt, this increases the tension between ES and RS on the other hand and TE on the other, which arises following an improvement in home productivity, and therefore diminishes the gains from generating a RER appreciation and a decrease in labor effort. As reported in columns (II) of Table 3, welfare gains from switching to the Taylor rule fall from 0.07 to 0.04 percent of consumption. Conversely, with $N F D R=1$, the amplified RS mechanism shifts even more wealth away from the country experiencing productivity gains, and so further diminishes the degree of consumption risk sharing. Consequently, the gains from exchange rate stabilization in the high debt scenario increase from 0.25 to 0.32 percent of consumption.

Overall, however, the main conclusions of the previous section remain robust to the change in the degree of 

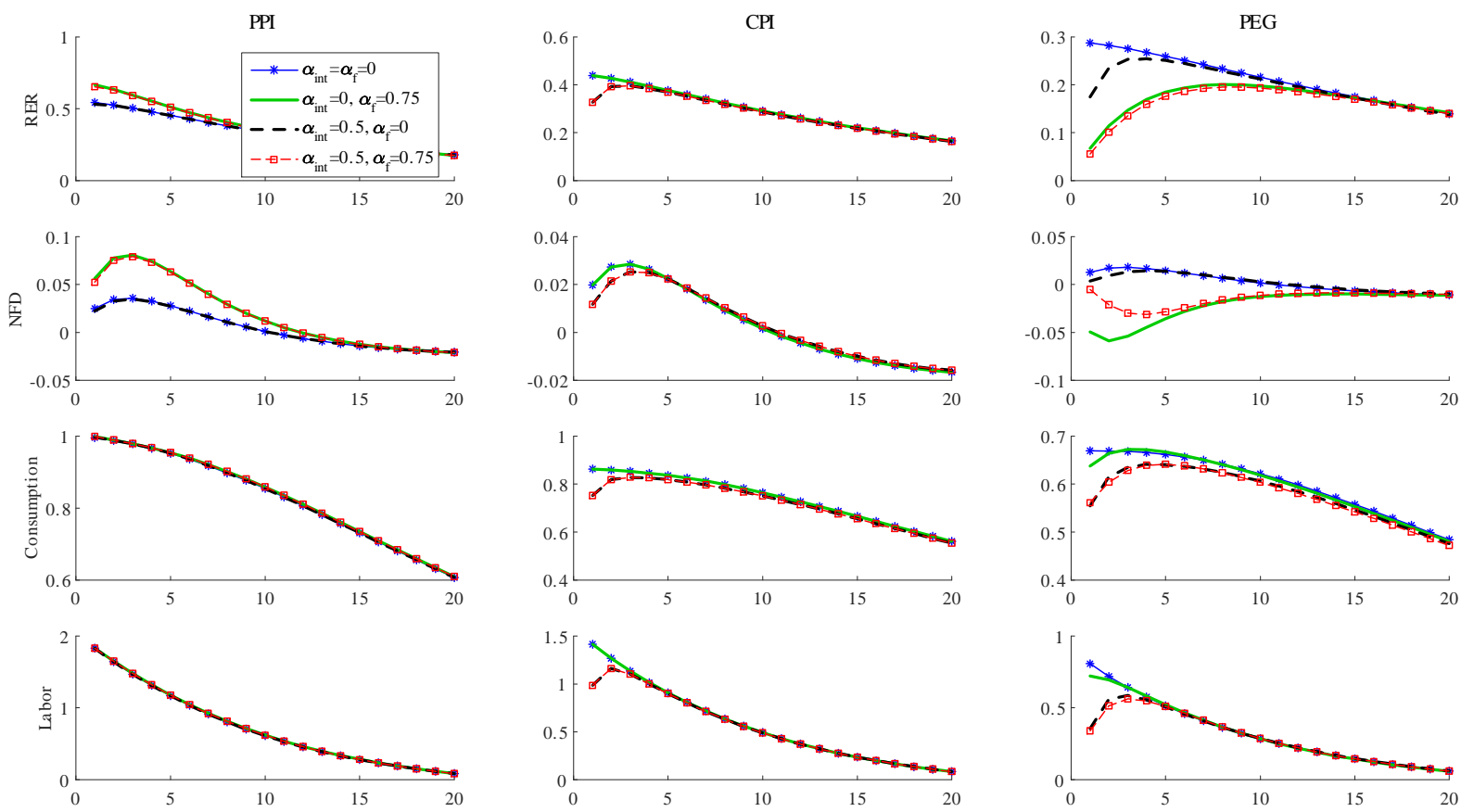

Figure 4: Impact of price stickiness structure on the model dynamics following a positive shock to home productivity; $N F D R=0$ in all panels. Vertical axis shows percent deviations of variables from their steady-state values.

exchange rate pass-through.

\subsection{Import-Export Elasticity}

Import-export elasticity $\eta$ is one of the key parameters governing the transmission of idiosyncratic shocks across national borders. Before turning to the model results, it is worthwhile taking a closer look at the welfare effects of the terms of trade externality and its interaction with risk sharing. Under complete markets (not modeled here), the marginal utilities of home and foreign consumption are directly linked to the real exchange rate: $C_{t} / C_{t}^{*}=Q_{t}$ assuming $\log$ utility of consumption. If there are no deviations from purchasing power parity (so that $Q_{t}=1$ at all times), this condition strengthens to imply complete equalization of consumption across countries: $C_{t}=C_{t}^{*}$. On the other hand, when financial markets are incomplete the ratio of consumptions becomes a function of the real exchange rate and the risk premium: $C_{t} / C_{t}^{*}=f\left(Q_{t}, \varphi_{t}\right)$, with the functional form depending on the exact specification of market incompleteness. For a given level of the real exchange appreciation, which lowers domestic output and labor effort and increases purchasing 
power of home households, the overall change in consumer welfare depends also on (a) the response of home consumption to the RER movement, and (b) the degree to which home consumers increase their demand for imports and therefore share the wealth effect with foreign households. In our model, the level of foreign debt interacts with the value of import-export elasticity to affect the magnitudes of (a) and (b) ${ }^{21}$ It is therefore crucial to explore whether our policy recommendations generalize to a wider range of this parameter's values. The answer is generally "yes," with several caveats we explore below.

A decrease in $\eta$ diminishes the degree of the cross-country wealth transfer following technology shocks. Using the example of an improvement in home productivity described in the previous section, consider the response of macroeconomic indicators when we set $\eta=0.6$, shown in Figure 5. Given the lower substitutability of imports and exports, the ES mechanism requires a much sharper depreciation to shift the global demand to the home good. Additionally, for any given level of RER depreciation, the lower substitutability weakens the RS channel by keeping a larger share of the positive wealth effect in the home country. Since home consumers cannot readily substitute towards imports, demand for foreign goods is lower than in the baseline calibration (with $\eta=1.5$ ), thereby preventing foreign households from fully sharing in the home economy windfall. As a result, the range of cross-border risk sharing for all the monetary policy functions considered in the paper shifts down and expands to [0.3123, 0.7827] (columns (III) of Table 3). Since both the ES and the RS mechanisms require a more depreciated RER to operate, the tension between them and the TE objective (which requires an appreciation) is larger, requiring the central bank to carry out a more careful balancing act of reducing home labor effort versus increasing the degree of risk sharing.

Given our modeling and calibration assumptions, the optimal policy (Taylor rule) takes advantage of the TOT externality, but now the central bank optimally sets $\rho_{q}>0$ to mitigate the risk-sharing gap between the two countries. More specifically, while the RER appreciates for all considered values of $\rho_{q}$, given $\rho_{\pi}=1.1$, the consumption-RER correlation increases by 0.1616 when $\rho_{q}$ is increased from 0 to 1.3. In this case, the central bank improves consumer welfare by about 5 percent of steady state consumption relative to the policy of PPI targeting. Notice that, once again, the optimal policy does not fully maximize risk sharing; in fact,

\footnotetext{
${ }^{21}$ The relationship between import-export elasticity, TOT externality, and the structure of international financial markets has been explored in De Paoli (2009, 2009b) and Rabitsch (2012). The authors, however, do not explicitly quantify changes in the level of risk sharing and its impact on welfare for different calibrations and policy specifications of their models.
} 

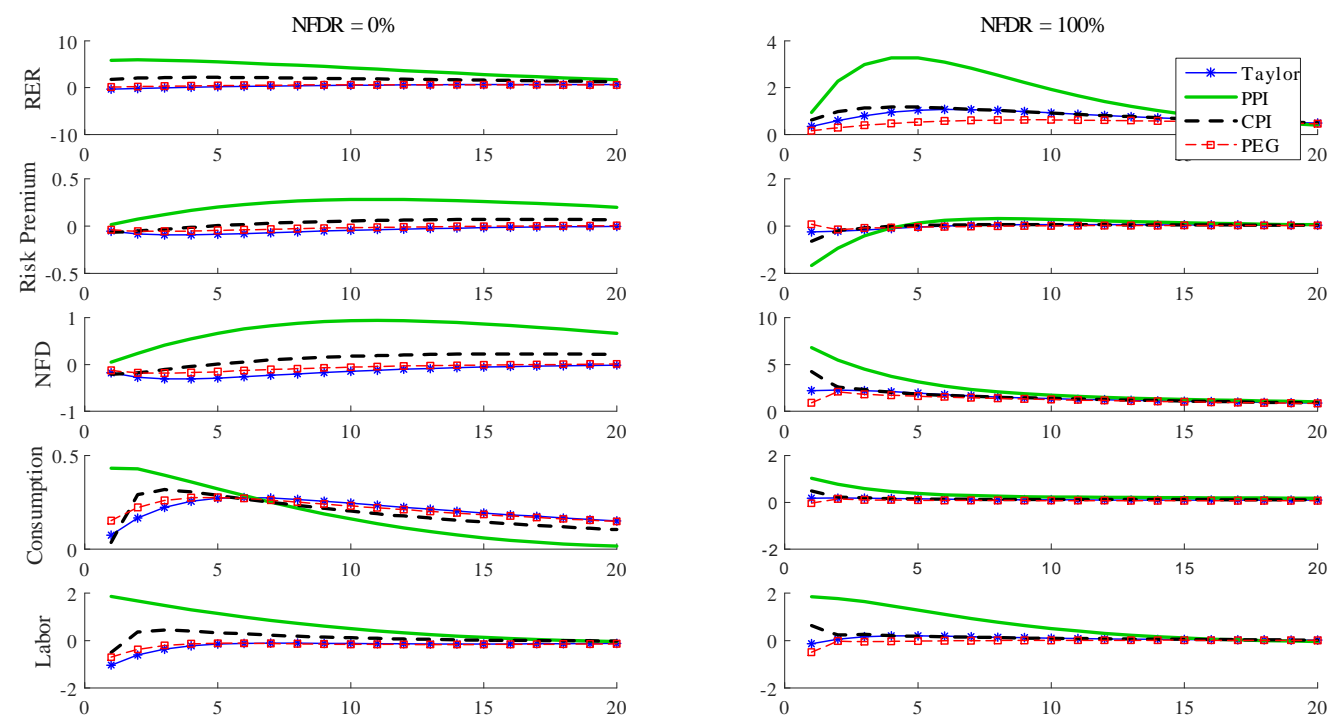

Figure 5: Impact of monetary policy choice on the model dynamics following a positive shock to home productivity for $\eta=0.6$. In both panels, we set the Taylor rule parameters to their optimal levels. Vertical axis shows percent deviations of variables from their steady-state values.

PPI targeting, by allowing for a sharp depreciation, increases the purchasing power of foreign consumers and thus allows for a slightly higher consumption-RER correlation. However, the risk-sharing loss from switching to the optimal Taylor rule is fairly small (see Table 3) and is offset by a significant welfare-improving decrease in home labor effort. The left panel of Figure 6 shows that welfare gains from following the Taylor rule, which allows the RER to appreciate, are inversely related to the degree of import-export substitutability.

Just as in the baseline case, the addition of foreign debt shifts the range of consumption-RER correlations even further down: $\operatorname{Corr}\left(C / C^{*}, Q\right)$ now varies from -0.4998 (corresponding to Taylor rule with $\rho_{\pi}=1.2$ and $\rho_{q}=2$ ) to 0.5576 under complete consumer price stability. Once again, the RS objective dominates, and the home central bank chooses a policy that maximizes international risk sharing; the optimal policy delivers an improvement in welfare equivalent to 0.08 percent of steady state consumption (again, relative to PPI targeting). Interestingly, unlike in the analysis above, strict CPI targeting outperforms exchange rate peg in this regard for values of $\eta$ of 1.1 and lower (see the right panel of Figure 6). Figure 5 helps to understand this result. As the value of $\eta$ declines, more and more of the wealth effect from higher productivity remains in the home country (since the RS channel is weakened). This, in effect, mitigates the disproportional transfer 
of wealth to the foreigners and makes RER depreciation less detrimental. CPI targeting delivers more of a depreciation than does the nominal peg, thus improving risk sharing.
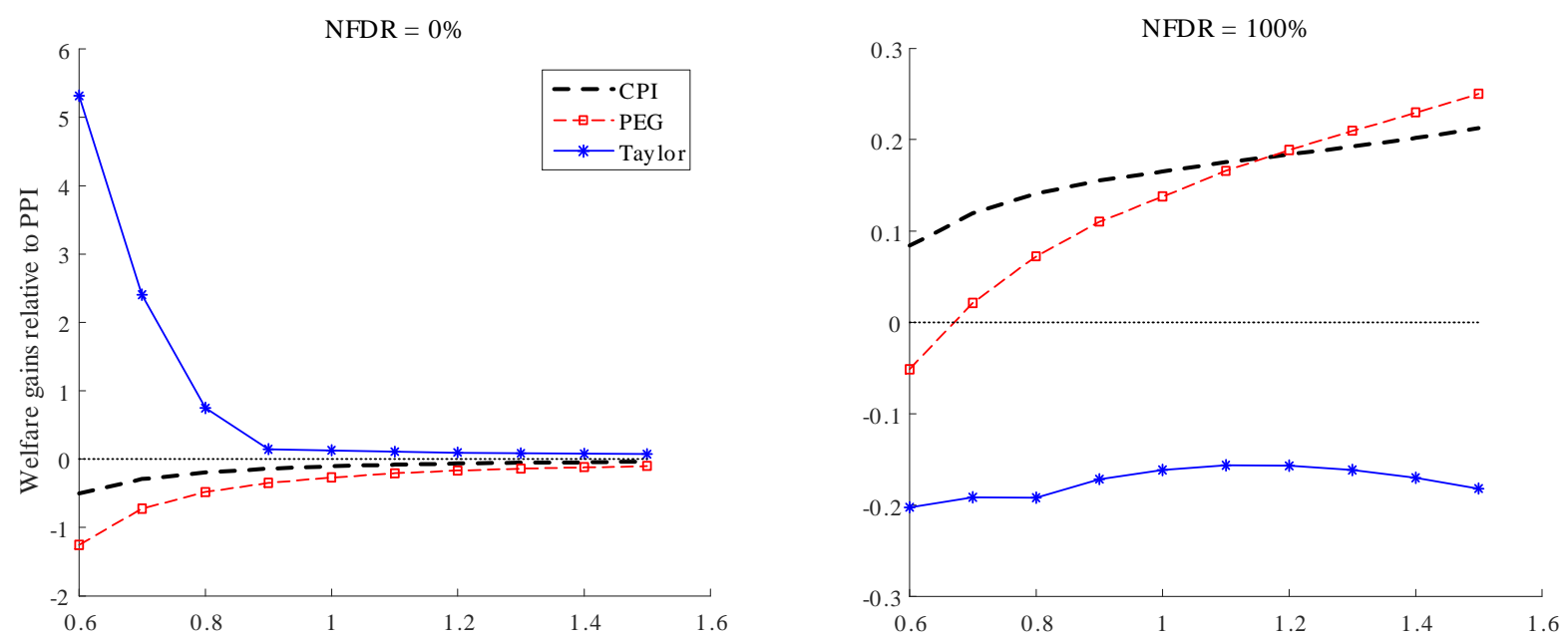

Figure 6: Welfare gains, measured in percent of steady state consumption, relative to the policy of strict producer inflation targeting (PPI) for different values of import-export elasticity $\eta$. "Taylor" refers to the Taylor rule that maximizes consumer welfare.

Once the value of import-export elasticity increases sufficiently to allow RER appreciation to transfer the wealth effect abroad via a shift in demand to foreign goods, the nominal peg once again becomes more desirable as it best stabilizes the value of debt and the associated interest payments in the face of business cycles.

\subsection{Trade Openness}

As the last two columns of Table 3 demonstrate, our results are qualitatively unaffected by the degree of trade openness $\mu$ : responding to RER movements is optimal only in the presence of high foreign debt. Equations (12) and (13) indicate that the magnitudes of the two debt channels do not depend of the value of $\mu$. However, as the home country's import share increases (corresponding to a lower value of $\mu$ ), the TE channel becomes more powerful, since a larger share of the basket is produced by foreigners.

In the absence of foreign debt, the degree of international risk sharing remains high under all considered policy options. Therefore, the gains from the policy that can deliver the most appreciated RER - again, 
Taylor rule with a very loose stance on CPI inflation and no response to exchange rates - albeit at the cost of lower risk sharing, increase relative to the benchmark scenario (from 0.07 to 0.14 percent of steady state consumption). Figure 7 ranks the different policy options in terms of the welfare gains relative to PPI for a range of values of the parameter $\mu$. Conversely, a high level of foreign debt combined with greater trade openness significantly lowers the consumption-RER correlation, which now spans the $[-0.9805,0.5656]$ range. The reason for the deterioration of risk sharing lies in the greater desire of home consumers for foreign goods, exacerbating the transfer of the wealth effect away from the home country. The central bank therefore gives preference to the policy (a strict peg) that can best stabilize the RER and thereby increase cross-country risk sharing. For $\mu=0.5$, the welfare gain from deviating from the policy of complete price stability more than triples to 0.77 percent of consumption relative to the baseline calibration of $\mu=0.75$.
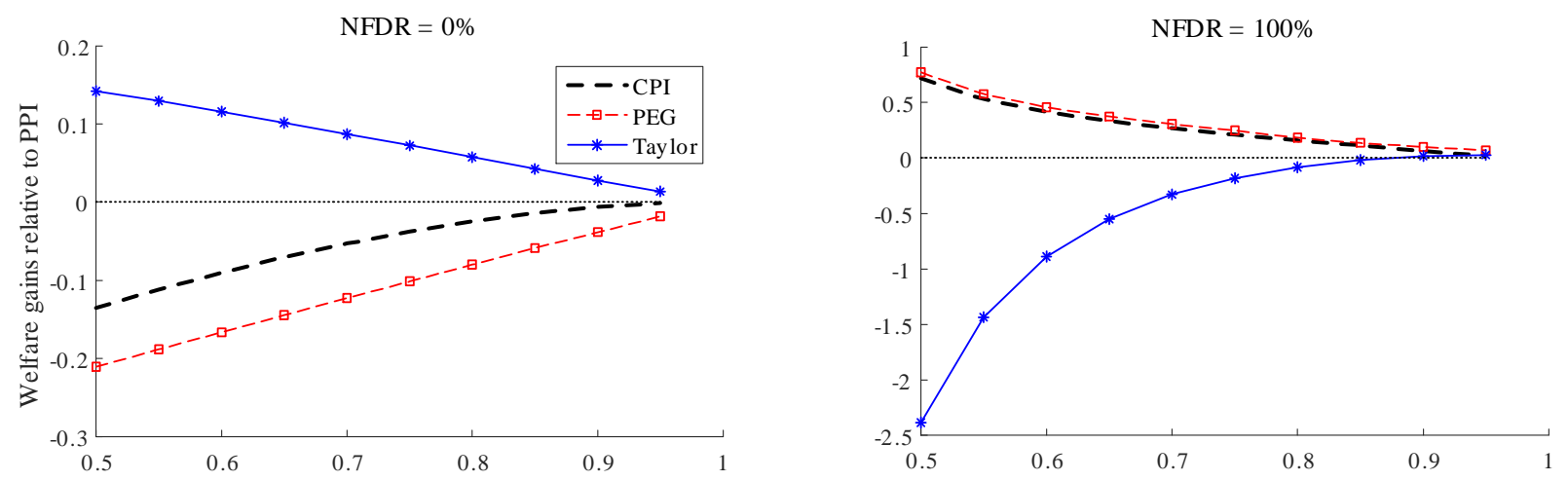

Figure 7: Welfare gains, measured in percent of steady state consumption, relative to the policy of strict producer inflation targeting (PPI) for different values of home bias $\mu$. "Taylor" refers to the Taylor rule that maximizes consumer welfare; the optimal parameter configurations are independent of the value of $\mu$ and are equal to $\left(\rho_{\pi}, \rho_{q}\right)=$ $(1.1,0)$ for $N F D R=0$ and to $\left(\rho_{\pi}, \rho_{q}\right)=(3,2)$ for $N F D R=1$.

As $\mu$ approaches unity (making the home economy an autarky), the gains from exploiting the TOT externality disappear. Since the share of imports in consumption goes to zero, it is not possible to shift the disutility of production to the foreign households. All considered policy options, therefore, deliver virtually the same level of welfare in a closed economy setting. 


\section{Conclusion}

Prompted by the observation that international financial imbalances have increased markedly in the last two decades, we explore the impact of foreign debt on the optimal real exchange rate policy of a small open economy that faces a risk premium when borrowing from abroad in foreign currency. Foreign debt affects the functioning of the domestic markets via two channels. The risk premium channel reacts to changes in the debt-to-GDP ratio and magnifies cross-border capital flows following idiosyncratic country shocks. The debt valuation channel links movements in terms of trade to the real value of debt, which we assume is denominated in foreign currency. These channels interact with one another to lower the degree of cross-country risk sharing relative to the specification with no international indebtedness.

Via these two channels, high levels of foreign debt change the relative importance of the three openeconomy objectives of monetary policy: ensuring efficient adjustment of international prices following idiosyncratic productivity shocks (expenditure-switching mechanism), manipulating terms of trade to lower domestic labor effort (terms-of-trade externality), and promoting cross-country consumption risk sharing. We find that at low debt levels, the degree of risk sharing is little affected by the choice of the monetary policy regime; the central bank can therefore exploit the terms-of-trade externality to maximize consumer welfare. In this setting, Taylor rule with very low weight on CPI inflation and zero weight on the real exchange rate delivers the most appreciated real exchange rate. On the other hand, the presence of high levels of foreign debt significantly lowers the range of consumption-real exchange rate correlations, making risk sharing the primary objective of the central bank. Strict exchange rate targeting maximizes welfare by mitigating the detrimental debt valuation effects on home consumers.

Our results are robust to the degree of trade openness, but are sensitive to the assumed value of the importexport elasticity, which governs the magnitude and direction of the cross-country wealth transfer following country-specific shocks. At low values of this parameter, the expenditure-switching effect of exchange rate fluctuations is greatly reduced, preventing the wealth effect of productivity shocks from crossing national borders. In this scenario, the central bank has a greater incentive to improve consumer risk sharing. At high debt levels, CPI targeting outperforms the nominal exchange rate peg for values of import-export elasticity below 1.1. This finding qualifies the "fear of floating" argument proposed in by Calvo and Reinhart (2002). 
Even in the face of potentially large debt valuation effects produced by exchange rate fluctuations, the desirability of fixing the nominal exchange rate depends on the country's import-export characteristics.

Our quantitative predictions are of course contingent on several simplifying model assumptions. It is likely that the currency of denomination and the elasticity of the cost of foreign borrowing are not independent of the debt level or the monetary policy stance, potentially altering the risk premium channel outlined in our paper. Moreover, international portfolios of borrowing and lending countries are composed of multiple financial instruments in addition to bond holdings; therefore, the degree of risk sharing under any given monetary policy could be different from that reported in our study, with the corresponding consequences for the optimal conduct of the central bank. Thus, our results represent a first step towards a more complex analysis of the interaction between net foreign asset positions and the choice of monetary policy. Finally, more attention could be paid to the distinction between private and government borrowing from abroad and the possibility of sovereign default. We leave the exploration of these issues to future research. 


\section{A Model Solution}

\section{A.1 Firms}

The optimal price for an intermediate good variety is given by

$$
\tilde{P}_{H, t}=\frac{\sigma_{i n t}}{\sigma_{i n t}-1} \frac{E_{t} \sum_{j=t}^{\infty}\left(\alpha_{i n t} \beta\right)^{j-t} \lambda_{j} P_{H, j}^{\sigma_{i n t}} Y_{H, j} M C_{j}}{E_{t} \sum_{j=t}^{\infty}\left(\alpha_{i n t} \beta\right)^{j-t} \lambda_{j} P_{H, j}^{\sigma_{i n t}} Y_{H, j}},
$$

where $M C_{t}$ is the nominal marginal cost of production:

$$
M C_{t}=\frac{R_{t}^{\nu} W_{t}^{1-\nu}}{Z_{t} \nu^{\nu}(1-\nu)^{1-\nu}}
$$

We consider a symmetric equilibrium in which every firm that gets a chance to reset its prices in period $t$ will set it to the same value; therefore, optimal prices are not denoted by a firm subscript $f$. Given the price-setting behavior of individual firms, the aggregate price index of the composite intermediate good can be written as

$$
P_{H, t}^{1-\sigma_{i n t}}=\left(1-\alpha_{i n t}\right) \tilde{P}_{H, t}^{1-\sigma_{i n t}}+\alpha_{i n t} P_{H, t-1}^{1-\sigma_{i n t}}
$$

Analogously, each final good variety producer finds it optimal to charge

$$
\tilde{P}_{t}(i)=\frac{\sigma_{f}}{\sigma_{f}-1} \frac{E_{t} \sum_{j=t}^{\infty} \lambda_{j}\left(\alpha_{f} \beta\right)^{j-t} P_{j}^{\sigma_{f}} Y_{j} M C F_{j}}{E_{t} \sum_{j=t}^{\infty} \lambda_{j}\left(\alpha_{f} \beta\right)^{j-t} P_{j}^{\sigma_{f}} Y_{j}}
$$

where $P_{t}=\left[\int_{0}^{1} P_{t}(i)^{1-\sigma_{f}} d i\right]^{\frac{1}{1-\sigma_{f}}}$, and $M C F_{t}$ captures the marginal cost of inputs:

$$
M C F_{t}=\left[\mu P_{H, t}^{1-\eta}+(1-\mu)\left(S_{t} P_{F, t}^{*}\right)^{1-\eta}\right]^{\frac{1}{1-\eta}}
$$

\section{A.2 Households}

The demand for household $h$ 's labor services, given its wage, is

$$
\begin{aligned}
L_{t}(h) & =\left[\frac{W_{t}(h)}{W_{t}}\right]^{-\sigma_{l}} \frac{L_{t}}{M} \\
L_{t} & =M^{\frac{1}{1-\sigma_{l}}}\left[\int_{0}^{M} L_{t}(h)^{\frac{\sigma_{l}-1}{\sigma_{l}}} d h\right]^{\frac{\sigma_{l}}{\sigma_{l}-1}} \\
W_{t} & =M^{\frac{1}{\sigma_{l}-1}}\left[\int_{0}^{M} W_{t}(h)^{1-\sigma_{l}} d h\right]^{\frac{1}{1-\sigma_{l}}},
\end{aligned}
$$


where the last equation presents the aggregate wage level. The scaling factor $M^{\frac{1}{1-\sigma_{l}}}$ is necessary to maintain the aggregate relationship $L_{t}=\int_{0}^{1} L_{t}(f) d f=M L_{t}(h)$. Together with the expression $K_{t}=M K_{t}(h)$ this will ensure that the production function exhibits constant returns to scale. Additionally, in the steady state, the aggregate wage $W$ will equal the individual wage $W(h)$.

For simplicity, in the equations below we drop the household subscript $h$.

$$
\begin{aligned}
\lambda_{t} & =\frac{1}{C_{t}^{\Theta} P_{t}} \\
\frac{1}{1+i_{t}} & =\beta E_{t}\left[\left(\frac{C_{t+1}}{C_{t}}\right)^{-\Theta} \frac{P_{t}}{P_{t+1}}\right] \\
\frac{1}{1+i_{t}^{*}+\varphi_{t}} & =\beta E_{t}\left[\left(\frac{C_{t+1}}{C_{t}}\right)^{-\Theta} \Delta S_{t+1} \frac{P_{t}}{P_{t+1}}\right] \\
\left\{1+\psi\left[\frac{K_{t}}{K_{t-1}}-1\right]\right\} & =\beta E_{t}\left[\frac{C_{t+1}}{C_{t}}\right]^{-\Theta}\left\{1-\delta+R_{t+1}+\frac{\psi}{2}\left[\left(\frac{K_{t+1}}{K_{t}}\right)^{2}-1\right]\right\} \\
C_{H, t} & =\mu\left[\frac{P_{H, t}}{P_{t}}\right]^{-\eta} C_{t}, \quad C_{F, t}=(1-\mu)\left[\frac{S_{t} P_{F, t}^{*}}{P_{t}}\right]^{-\eta} C_{t}
\end{aligned}
$$

Here $i_{t}$ is the yield on the one-period nominal risk-free bond, which can be easily derived from the set of state-contingent bonds $D_{t}$. Following Cochrane (2001), chapter 3, let $p(D)=\sum_{s} p c(s) D(s)$ be the price of a portfolio $D$ of state-contingent bonds; here $s$ 's denote states of nature, $p c(s)$ is the price of a bond that pays one dollar next period contingent on the state $s$ occurring, and $D(s)$ is the number of such claims in portfolio $D$. If $\pi(s)$ is the probability of state $s, p(D)=\sum_{s} \pi(s)[p c(s) / \pi(s)] D(s)=E_{t}\left[\Delta_{t, t+1} D_{t}\right]$, where $\Delta_{t, t+1}$ is the stochastic discount factor. Now consider a bond that costs 1 dollar in period $t$ and pays $I$ dollars in all states in $t+1$. We then can write $I_{t}=1 / E\left(\Delta_{t, t+1}\right)$ and let $i_{t} \equiv \ln I_{t}$.

We assume that every household which chooses its wage in period $t$ sets it to the same new value:

$$
\tilde{W}_{t}^{\sigma_{l} \chi+1}=\frac{\sigma_{l}}{\sigma_{l}-1} \frac{E_{t} \sum_{j=t}^{\infty}\left(\alpha_{w} \beta\right)^{j-t} W_{j}^{\sigma_{l}(\chi+1)} L_{j}^{1+\chi}}{E_{t} \sum_{j=t}^{\infty}\left(\alpha_{w} \beta\right)^{j-t} \lambda_{j} W_{j}^{\sigma_{l}} L_{j}}
$$

Similar to the derivations of the aggregate price level given firms' first-order conditions, the aggregate wage level is given by

$$
W_{t}^{1-\sigma_{l}}=\left(1-\alpha_{w}\right) \tilde{W}_{t}^{1-\sigma_{l}}+\alpha_{w} W_{t-1}^{1-\sigma_{l}}
$$




\section{B Data Sources and Description}

Unless otherwise indicated, all data are taken from OECD.Stat database and refer to the 1980Q1-2011Q3 period (or at the earliest available date following 1980). The statistics reported in Table 2 are based on the data for Czech Republic, Estonia, Hungary, Poland, Russian Federation, Slovak Republic, and Slovenia.

$P_{t}$ : Consumer prices, all items, $2005=100$

$Y_{t}$ : Gross domestic product, current prices, deflated by $P_{t}$

$C_{t}$ : Private final consumption expenditure, current prices, deflated by the $P_{t}$

$I_{t}$ : Gross fixed capital formation, current prices, deflated by the $P_{t}$

$C A_{t}$ : Current account balance, percent of GDP

$G_{t}$ : General government final consumption expenditure, deflated by the $P_{t}$

$\pi_{t}$ : Inflation rate, calculated as $\log \left(P_{t} / P_{t-1}\right)$

$N F W_{t}$ : Net foreign assets (Lane and Milesi-Ferretti, EWN II update for the web, August 2009); annual data for the 1970-2007 period

$Q_{t}$ : Bank for International Settlements effective real exchange rate index

\section{References}

[1] Adolfson, M., Laséen, S., Lindé, J., Villani, M., 2007. Bayesian Estimation of an Open Economy DSGE Model with Incomplete Pass-Through. Journal of International Economics, 72, 481-511.

[2] Benigno, G., Benigno, P., 2006. Designing Targeting Rules for International Monetary Policy Cooperation. Journal of Monetary Economics, 53, 473-506.

[3] Benigno, G., Benigno, P., 2003. Price Stability in Open Economies. Review of Economic Studies, 70, $743-764$.

[4] Benigno, G., Thoenissen, C., 2008. Consumption and Real Exchange Rates with Incomplete Markets and Non-Traded Goods. Journal of International Money and Finance, 27, 926-948. 
[5] Benigno, P., 2009. Price Stability with Imperfect Financial Integration. Journal of Money, Credit and Banking, 41, 121-149.

[6] Bils, M., Klenow, P., 2004. Some Evidence on the Importance of Sticky Prices. Journal of Political Economy, 112, 947-985.

[7] Blanchard, O., Giavazzi, F., Sa, F., 2005. International Investors, the U.S. Current Account, and the Dollar. Brookings Papers on Economic Activity, 2005, 1-49.

[8] Bouvatier, V., 2007. Are International Interest Rate Differentials Driven by the Risk Premium? The Case of Asian Countries. Economics Bulletin, 5, 1-14.

[9] Calvo, G., 1983. Staggered Prices in a Utility Maximizing Framework. Journal of Monetary Economics, $12,383-398$.

[10] Calvo, G., Reinhart, C., 2002. Fear of Floating. The Quarterly Journal of Economics, 117, 379-408.

[11] Campa, M., Goldberg, L., 2005. Exchange Rate Pass-Through into Import Prices. Review of Economics and Statistics, 87, 679-690.

[12] Canzoneri, M., Cumby, R., Diba, B., 2007. The Cost of Nominal Rigidity in NNS Models. Journal of Money, Credit and Banking, 39, 1563-1586.

[13] Chari, V.V., Kehoe, P., McGrattan, E., 2002. Can Sticky Price Models Generate Volatile and Persistent Real Exchange Rates? Review of Economic Studies, 69, 533-563.

[14] Christiano, L., Trabandt, M., Walentin, K., 2011. Introducing Financial Frictions and Unemployment into a Small Open Economy Model. Journal of Economic Dynamics and Control, 35, 1999-2041.

[15] Cochrane, J., 2001. Asset Pricing. Princeton University Press.

[16] Cole, H., Obstfeld, M., 1991. Commodity Trade and International Risk Sharing: How Much Do Financial Markets Matter? Journal of Monetary Economics, 28, 3-24.

[17] Collard, F., Juillard, M., 2003. Stochastic Simulations with DYNARE. A Practical Guide. CEPREMAP (http://www.cepremap.cnrs.fr/dynare/). 
[18] Collard, F., Juillard, M., 2001. Accuracy of Stochastic Perturbation Methods: The Case of Asset Pricing Models. Journal of Economic Dynamics and Control, 25, 979-999.

[19] Corsetti, G., Dedola, L., Leduc, S., 2010. Optimal Monetary Policy in Open Economies. In Friedman, B., Woodford, M., (eds.), Handbook of Monetary Economics, volume 3, 861-933.

[20] Corsetti, G., Dedola, L., Leduc, S., 2008. International Risk Sharing and the Transmission of Productivity Shocks. Review of Economic Studies, 75, 443-473.

[21] Corsetti, G., Pesenti, P., 2005. International Dimensions of Optimal Monetary Policy. Journal of Monetary Economics, 52, 281-305.

[22] Corsetti, G., Pesenti, P., 2001. Welfare and Macroeconomic Interdependence. The Quarterly Journal of Economics, 116, 421-445.

[23] Cova, P., Søndergaard, J., 2004. When should monetary policy target the exchange rate? Royal Economic Society Annual Conference, Paper Number 51.

[24] Demirel, U., 2009. The Transmission of Foreign Interest Rate Shocks to a Small-Open Economy: The Role of External Debt and Financial Integration. The B.E. Journal of Macroeconomics, 9, Art. 3(Contributions).

[25] De Paoli, B., 2009. Monetary Policy and Welfare in a Small Open Economy. Journal of International Economics, 77, 11-22.

[26] De Paoli, B., 2009b. Monetary Policy under Alternative Asset Market Structures: The Case of a Small Open Economy. Journal of Money, Credit and Banking, 41, 1301-1330.

[27] Devereux, M., Engel, C., 2007. Expenditure Switching Versus Real Exchange Rate Stabilization: Competing Objectives for Exchange Rate Policy. Journal of Monetary Economics, 54, 2346-2374.

[28] Devereux, M., Engel, C., 2003. Monetary Policy in the Open Economy Revisited: Price Setting and Exchange-Rate Flexibility. Review of Economic Studies, 70, 765-783. 
[29] Eicher, T., Schubert, S., Turnovsky, S., 2008. Dynamic Effects of Terms of Trade Shocks: The Impact on Debt and Growth. Journal of International Money and Finance, 27, 876-896.

[30] Elekdag, S., Justiniano, A., Tchakarov, I., 2006. An Estimated Small Open Economy Model of the Financial Accelerator. IMF Staff Papers, 53, No. 2.

[31] Enders, Z., Müller, G., 2009. On the International Transmission of Technology Shocks. Journal of International Economics, 78, 45-59.

[32] Fischer, S., 2001. Exchange Rate Regimes: Is the Bipolar View Correct? The Journal of Economic Perspectives, 15, 3-24.

[33] Friedman, M., 1953. The Case for Flexible Exchange Rates. In Essays in Positive Economics (Chicago: University of Chicago Press) 157-203.

[34] Galí, J., Monacelli, T., 2005. Monetary Policy and Exchange Rate Volatility in a Small Open Economy. Review of Economic Studies, 72, 707-734.

[35] Ghironi, F., Lee, J., Rebucci, A., 2015. The Valuation Channel of External Adjustment. Journal of International Money and Finance, 57, 86-114.

[36] Gourinchas, P.-O., 2008. Valuation Effects and External Adjustment: A Review. In Cowan, K., Edwards, S., Valdés, R., Loayza, N. (series eds.), Schmidt-Hebbel, K. (ed.), Current Account and External Financing, edition 1, volume 12, 195-236. Central Bank of Chile.

[37] Gourinchas, P.-O., Rey, H., 2007. From World Banker to World Venture Capitalist: U.S. External Adjustment and the Exorbitant Privilege. In Clarida, R. (ed.), G7 Current Account Imbalances: Sustainability and Adjustment, University of Chicago Press.

[38] Kim, J., Kim, S., Schaumburg, E., Sims, C., 2008. Calculating and Using Second-Order Accurate Solutions of Discrete Time Dynamic Equilibrium Models. Journal of Economic Dynamics and Control, $32,3397-3414$.

[39] Kollmann, R., 2004. Welfare Effects of a Monetary Union: The Role of Trade Openness. Journal of the European Economic Association, 2, 289-301. 
[40] Lane, P., Milesi-Ferretti, G., 2001. Long-Term Capital Movements. NBER Macroeconomics Annual $2001,16,73-136$

[41] Levy-Yeyati, E., Sturzenegger, F., 2005. Classifying Exchange Rate Regimes: Deeds vs. Words. European Economic Review, 49, 1603-1635.

[42] Mumtaz, H., Oomen, O.,Wang, J., 2006. Exchange Rate Pass-Through into U.K. Import Prices. The Bank of England Working paper No 312.

[43] Mykhaylova, O., 2011. Welfare Implications of Regional Asymmetries in a Monetary Union. The B.E. Journal of Macroeconomics, 11, Art. 39(Topics).

[44] Mykhaylova, O., Staveley-O'Carroll, J., 2014. International Transmission of Productivity Shocks with Nonzero Net Foreign Debt. The B.E. Journal of Macroeconomics (Contributions), 14, 579-624.

[45] Nakamura, E., Steinsson, J. 2008. Five Facts about Prices: A Reevaluation of Menu Cost Models. The Quarterly Journal of Economics, 123, 1415-1464.

[46] Obstfeld, M., Rogoff, K., 2002. Global Implications of Self-Oriented National Monetary Rules. The Quarterly Journal of Economics, 117, 503-535.

[47] Obstfeld, M., Rogoff, K., 1998. Risk and Exchange Rates. In Helpman, E., Sadka, E., (eds.), Contemporary Economic Policy: Essays in Honor of Assaf Razin, Cambridge University Press.

[48] Rabitsch, K., 2012. The Role of Financial Market Structure and the Trade Elasticity for Monetary Policy in Open Economies. Journal of Money, Credit and Banking, 44, 603-629.

[49] Reinhart, C., 2000. Mirage of Floating Exchange Rates. American Economic Review Papers and Proceedings, 90, 65-70.

[50] Schmitt-Grohé, S., Uribe, M., 2004. Solving Dynamic General Equilibrium Models Using a Second-Order Approximation to the Policy Function. Journal of Economic Dynamics and Control, 28, 755-775. 
[51] Selaive, J., Tuesta, V., 2003. Net Foreign Assets and Imperfect Pass-Through: The Consumption Real Exchange Rate Anomaly. Board of Governors of the Federal Reserve System, International Finance Discussion Paper No. 764.

[52] Senay, O., 2008. Interest Rate Rules and Welfare in Open Economies. Scottish Journal of Political Economy, 55, 300-329.

[53] Taylor, J., 1999. Robustness and Efficiencies of Monetary Policy Rules as Guidelines for Interest Rate Setting by the European Central Bank. Journal of Monetary Economics, 43, 655-679.

[54] Viani, F., 2010. International financial flows, real exchange rates and cross-border insurance. Banco de Espana Working Paper No. 1038.

[55] Wang, J., 2010. Home Bias, Exchange Rate Disconnect, and Optimal Exchange Rate Policy. Journal of International Money and Finance, 29, 55-78.

[56] Wesche, K., 2003. Monetary Policy in Europe: Evidence from Time-Varying Taylor Rules. Bonn Econ Discussion Papers bgse21_2003, University of Bonn, Germany.

[57] Woodford, M., 1999. Optimal Monetary Policy Inertia. Manchester School, University of Manchester, 67, 1-35, Supplement. 


\begin{tabular}{|llll|}
\hline Parameter & Description & Value \\
\hline \hline$\Theta$ & Relative risk aversion & 1 & \\
$\chi$ & Inverse of Frisch labor elasticity & 3 & \\
$\mu$ & Consumption home bias (domestic good) & 0.75 & \\
$\eta$ & Import/export elasticity of substitution & 1.5 & \\
$Z$ & Matrix of technology coefficients & {$\left[\begin{array}{cc}0.95 & 0 \\
0 & 0.95\end{array}\right]$} \\
$\nu$ & Capital share in production & 0.33 & \\
$\delta$ & Capital depreciation rate & 0.025 & \\
$\sigma_{i n t}, \sigma_{f}$ & Elasticity of substitution between goods varieties & 6 & \\
$\sigma_{l}$ & Elasticity of substitution between labor varieties & 20 & \\
$\alpha_{i n t}, \alpha_{f}, \alpha_{w}$ & Degree of nominal rigidity & $0.50,0.75,0.70$ \\
$\xi$ & Risk premium on int'l borrowing/lending & 3 & \\
$\rho_{i}$ & Interest rate inertia in the Taylor Rule & 0.9 \\
\hline
\end{tabular}

Table 1: Benchmark parameter values 


\begin{tabular}{|l|ccc|ccc|}
\hline \multirow{2}{*}{} & \multicolumn{3}{|c|}{ Standard Deviations } & \multicolumn{3}{c|}{ Autocorrelations } \\
\cline { 2 - 7 } & Actual Data & $N F D R=0$ & NFDR $=1$ & Actual Data & NFDR $=0$ & NFDR $=1$ \\
\hline \hline$G D P$ & {$[1.84,9.44]$} & 1.31 & 2.31 & {$[0.52-0.92]$} & 0.83 & 0.58 \\
$C$ & {$[0.72,1.06]$} & 0.63 & 0.96 & {$[0.60-0.92]$} & 0.82 & 0.85 \\
$I$ & {$[1.34,4.01]$} & 3.58 & 4.97 & {$[0.63-0.92]$} & 0.87 & 0.81 \\
$Q$ & {$[0.63,3.12]$} & 0.45 & 1.41 & {$[0.56-0.76]$} & 0.76 & 0.77 \\
$C A / G D P$ & {$[1.53,5.97]$} & 0.03 & 3.72 & {$[0.50-0.88]$} & 0.66 & 0.51 \\
\hline
\end{tabular}

Table 2: Moments of the actual and simulated data for different calibrations of the steady-state net foreign debt level. All moments are based on the starting values for the Taylor rule parameters: $\rho_{i}=0.90, \rho_{\pi}=1.1$, and $\rho_{q}=0$. Standard deviations of all variables other than GDP are expressed relative to GDP. Both the actual data and the simulated series are of quarterly frequency, logged, and Hodrick-Prescott filtered using the smoothing parameter $\lambda=1600$. 


\begin{tabular}{|c|c|c|c|c|c|c|c|c|}
\hline \multirow[b]{2}{*}{$N F D R$} & \multicolumn{2}{|c|}{ (I) Baseline calibration } & \multicolumn{2}{|c|}{ (II) $\alpha_{f}=0$} & \multicolumn{2}{|c|}{ (III) $\eta=0.6$} & \multicolumn{2}{|c|}{ (IV) $\mu=0.5$} \\
\hline & 0 & 1 & 0 & 1 & 0 & 1 & 0 & 1 \\
\hline \multicolumn{9}{|c|}{ Panel A: Welfare gains (relative to PPI) } \\
\hline CPI & -0.0372 & 0.2122 & -0.0383 & 0.2774 & -0.4987 & 0.0840 & -0.1350 & 0.7177 \\
\hline PEG & -0.1011 & 0.2502 & -0.1016 & 0.3191 & -1.2533 & -0.0512 & -0.2103 & 0.7729 \\
\hline Taylor & 0.0723 & -0.1819 & 0.0407 & -0.0902 & 5.3107 & -0.2023 & 0.1420 & -2.3828 \\
\hline$\left(\rho_{\pi}, \rho_{q}\right)$ & $(1.1,0)$ & $(3.0,2.0)$ & $(1.1,0)$ & $(3.0,2.0)$ & $(1.1,1.3)$ & $(3,0)$ & $(1.1,0)$ & $(3.0,2.0)$ \\
\hline \multicolumn{9}{|c|}{ Panel B: $\operatorname{Corr}\left(C / C^{*}, Q\right)$} \\
\hline PPI & 0.9313 & 0.0925 & 0.9532 & -0.0345 & 0.7827 & 0.5535 & 0.8626 & -0.0615 \\
\hline CPI & 0.9510 & 0.4613 & 0.9510 & 0.4613 & 0.4545 & 0.5576 & 0.9282 & 0.4218 \\
\hline PEG & 0.9669 & 0.6390 & 0.9431 & 0.6261 & 0.3123 & 0.5028 & 0.9469 & 0.5656 \\
\hline Taylor & 0.8825 & -0.2471 & 0.9458 & -0.0367 & 0.7497 & 0.2677 & 0.7858 & -0.7468 \\
\hline \multicolumn{9}{|c|}{ Panel C: $\operatorname{Corr}\left(Z / Z^{*}, T O T\right)$} \\
\hline PPI & 0.9977 & 0.5573 & 0.9988 & 0.5373 & 0.9897 & 0.5752 & 0.9966 & 0.3651 \\
\hline CPI & 0.9842 & 0.6738 & 0.9842 & 0.6738 & 0.9646 & 0.7232 & 0.9722 & 0.5327 \\
\hline PEG & 0.9574 & 0.7633 & 0.9515 & 0.7482 & 0.9142 & 0.7555 & 0.9561 & 0.5782 \\
\hline Taylor & 0.8015 & 0.0408 & 0.9029 & 0.0601 & 0.6672 & 0.1049 & 0.7850 & -0.2128 \\
\hline
\end{tabular}

Table 3: Model performance under different monetary policy rules. Welfare gains are measured in percent of steady state consumption, relative to the policy of strict producer inflation targeting (PPI). Taylor refers to the Taylor rule that maximizes consumer welfare, with the corresponding optimal parameters specified in the parentheses below the welfare gains numbers in Panel A. 